\title{
SETTLEMENT OF LIKA AND THREE OTTOMAN NÂHIYES: NOVI, MEDAK AND BILAJ BARLETE IN THE 16TH CENTURY
}

\author{
Kornelija Jurin Starčević
}

Faculty of Humanities and Social Sciences, University of Zagreb

ABSTRACT

\begin{abstract}
The paper analyses demographic, landholding and economic structure in Lika, namely in the three Ottoman nâbiyes founded in the second half of the $16^{\text {th }}$ century - the nâbiyes of Novi, Medak and Bilaj Barlete, and reconstructs the course of settlement based on the preserved Ottoman tax registers from the $16^{\text {th }}$ century for the sancâks of Bosnia, Klis and Krka to which Lika belonged. The said nâhiyes were "clustered" geographically and administratively; they were three neighbouring administrative and judicial units in the area where the centre of administration over Ottoman Lika was situated. The area encompassed by the three nâbiyes become the nucleus of population density in Ličko polje. The paper records the changes between the census years in the number of settlement and population density, demographic movements, landholding structure and tax system. The paper devotes attention to the characteristics of the Ottoman recolonization policy, the efforts invested by the Ottoman government to repopulate Lika and describes the effects of the measures undertaken. The paper reconstructed the landowning structure based on the information from the tax registers.
\end{abstract}

\section{AIM, RESEARCH STARTING POINT, SOURCES AND HISTORIOGRAPHIC COVERAGE}

Recolonization and repopulation politics of the Ottoman Empire, its demographic characteristics, the characteristics of the sipâhî timâr system and the landholding system in Lika are still poorly researched topics. There was no systematic research of the demographic and economic history, and of the landholding relations in Lika during Ottoman rule in the $16^{\text {th }}$ and $17^{\text {th }}$ centuries although the past three decades did bring about a number of valuable historiographic contributions which illuminate individual aspects of the demographic, social and economic history of Lika during Ottoman rule. ${ }^{1}$

This paper aims to analyse demographic, landholding and economic structure of three Ottoman nâbiyes in Lika - Novi, Medak and Bilaj Barlete, and to reconstruct the course of settlement to the extent possible from preserved Ottoman sources

$1 \quad$ Nenad Moačanin, "Naseljenost Like i izvori feudalne rente početkom XVII. stoljeća pod turskom vlašcu," Historijski zbornik XLVI (1993): 61-65; Nenad Moačanin, "Ime Gospić u svjetlu turskih izvora," Croatica christiana periodica 26 (1990): 51-54; Marko Šarić, "Osmanski korijeni Gospića: nahija Novi u 16. i 17. stoljeću," Povijesni prilozi 42 (2012): 215-248. 
and literature. The nâbiyes were clustered geographically and administratively; these were three neighbouring administrative and judicial units in the area wherein the centre of management of Ottoman Lika was set up. Little is still known about the settlements of the area and their landholding relations, even though the area covered by the three nâhiyes was the nucleus of population density in Ličko polje. The nâbiyes of Medak and Bilaj Barlete have never been researched, while Novi was incorporated in the study of the Ottoman Gospić. ${ }^{2}$

This paper finds its main source in the Ottoman tax and land ownership registers or defters (tâpu tahrîr defteri) for the sancâks of Bosnia, Klis and Krka which is where Lika belonged in the $16^{\text {th }}$ and $17^{\text {th }}$ centuries. The registers used were the registers for the following years: $1528-30^{3}, 1550^{4}, 1574^{5}, 1585^{6}$ and $1604^{7}$. Some of these defters are icmâl or synoptic defters, while others are mufassal or detailed ones. ${ }^{8}$ In addition to the above, the $1528-30$ register is also important ${ }^{9}$ as it gives data on the soldiers paid in cash in the forts of the sancâk of Bosnia. The research has uncovered numerous individual documents in the Mühimme Defteri series (official registers of important affairs) which give information on the settlement of Lika.

Inspection of Ottoman tax registers for the sancâks of Bosnia, Klis and Krka enabled reconstruction of the demographic and economic situation in Lika, specifically, in the three nâhiyes once those have been established. Changes between census years in the number of settlements, population density, demographic movements, landholding structure and tax system are recorded. The paper then focuses on the characteristics of the Ottoman recolonization politics, namely the government efforts to repopulate Lika and the end results of the measures undertaken. It also aims to uncover or rather, give a rough sketch of basic directions of migrations from the notes of the census takers in the tax registers and the records in other relevant sources. The paper aims to answer the questions of the level of demographic devastation in the period of the conquest and colonisation of the

Šarić, “Osmanski korijeni Gospića," 215-248.

3 Başbakanlık Osmanlı Arşivi (henceforth BOA), Istanbul. Tapu Tahrir Defteri (henceforth TD) 157, TD 164.

4 BOA, TD 284.

5 BOA, TD 533.

6 BOA, TD 622.

7 Tapu ve Kadastro Genel Müdürlüğü, Kuyûd-i Kadime Arşiv (henceforth TK. KKA), Ankara. TD 119.

8 The difference in these defters is in the information giving potential of the sources; detailed defters are much richer as they give "detailed" description of the sources of income in a sancâk and the division of that income among the sipâhî, as opposed to the synoptic defters which give only overviews or the recapitulation of the most important data recorded in the detailed defters.

9 BOA, Maliyeden Müdevver Defterler (MAD) 540, 218-219. 
space, the course of demographic and economic recovery, population density, characteristics of the Ottoman tax and land policy and the implications of the policy on the landholding relations and population density in the nâbiyes of Medak, Novi and Bilaj Barlete.

The paper aims to contribute to the knowledge of social and demographic history of Lika using Ottoman sources primarily. Naturally, a fuller picture of the population density and landholding structure in Lika during Ottoman rule in the $16^{\text {th }}$ century will be created only following the research of demographic and economic characteristics of other nâhiyes of Lika (Cvituša, Perušić, Gračac and Zvonigrad) and Krbava.

As it has already been stated, the history of Lika during Ottoman rule has not been sufficiently researched historiographically, and the above mentioned three nâhiyes have not been the topic of individual research. Additionally, Ottoman studies are particularly rare. Ottoman studies have incorporated Lika in wider topics such as administrative and social history of the Bosnian eyâlet,$^{10}$ military history of the sancâks of Klis and Krka, or history of the Ottoman frontier zone (serhad) in present-day Croatia. ${ }^{11}$ Until the publishing of the Ottoman historical materials relevant for the sancâk of Klis which began with Fehim Dž. Spaho, ${ }^{12}$ it was predominantly western sources published by Radoslav Lopašić, ${ }^{13}$ Franjo Rački and Mijo Batinić, ${ }^{14}$ as well as Mile Bogović ${ }^{15}$ that dominated the studies of the history of Lika under Ottoman rule. Nenad Moačanin expanded the topic and the

$10 \quad$ Hazim Šabanović, Bosanski pašaluk. Postanak i upravna podjela (Sarajevo: Svjetlost, 1982), 59, 73 76, 210-212, 226-227; Hamdija Kreševljaković, Izabrana djela (Sarajevo: Veselin Masleša, 1991), 114-121.

11 Aladin Husić, "Vojne prilike u splitsko-zadarskom zaleđu u 16. stoljeću (osmanski serhat 15301573)," Prilozi za orijentalnu filologiju 56 (2006): 125-144; Aladin Husić, “Tvrđave Bosanskog sandžaka i njihove posade 1530. godine," Prilozi za orijentalnu filologiju 49 (1999): 189-230; Kornelija Jurin Starčević, "Vojne snage Kliškog i Krčko-ličkog sandžaka pred Kandijski rat osmanska vojska plaćenika," in Zbornik Mire Kolar Dimitrijević, ed. Damir Agičić (Zagreb: FF press and Odsjek za povijest Sveučilišta u Zagrebu, 2003), 79-95; Fehim Dž. Spaho, "Organizacija vojne krajine u sandžacima Klis i Krka u XVII. stoljeću," in Vojne krajine u jugoslovenskim zemljama u novom veku do Karlovačkog mira 1699.godine, ed. Čubrilović, Vasa (Beograd: SANU, 1989), 101-114.; Fehim Dž. Spaho, "Neke karakteristike razvitka varoških naselja u Kliškom sandžaku u XVI. i XVII. stoljeću," Prilozi za orijentalnu filologiju 38 (1989): 241-251.

12 Fehim Dž. Spaho et al., Opširni popis Kliškog sandžaka iz 1550. godine (Sarajevo: Orijentalni institut u Sarajevu, 2007).

13 Radoslav Lopašić, Spomenici Hrvatske krajine. Knjiga 1. Od godine 1409. do 1610. (Zagreb: Academia scientarium et artium Slavorum meridionalium 1884.)

14 Mijo Batinić, "Njekoliko priloga k bosanskoj crkvenoj povijesti," Starine JAZU XVII (1885): 115-145; Franjo Rački "Prilozi za geografsko-statistički opis Bosanskoga pašalika," Starine JAZU XIV (1882): 173-195.

15 Mile Bogović, “Takozvani Glavinićev opis Like i Krbave iz 1696. godine," Croatica Christiana Periodica 15, no. 27 (1991): 117 - 128. 
continued scientific valorisation of Ottoman sources on the history of Lika. ${ }^{16}$ More recently, Marko Šarić gave a significant contribution to the study of the history of Lika in the $16^{\text {th }}$ and $17^{\text {th }}$ centuries. ${ }^{17}$ In spite of valuable individual historiographic contributions which do shed light onto certain segments of Lika's history during Ottoman rule, knowledge about it is still inadequate, and Ottoman sources still insufficiently used. Therefore, lacking contemporary comparative studies which would compare the research of early researchers of Lika's past with the new knowledge from Ottoman sources, the works of the older generation of historians who studied Lika in the Ottoman period from Western sources found in Vienna, Graz and other archives are still indispensable references. We are here primarily referring to the work of Stjepan Pavičić; his study on migration and settlements is still a reference point in the research of historical and demographic issues, specifically the research of the population density and migration in Lika immediately before and during the Ottoman rule. ${ }^{18}$ Also, works recording Ottoman cultural heritage in Lika are extremely important. ${ }^{19}$ Even though historiographic knowledge on Lika under Ottoman rule to date has been incorporated in the synthesis of the history of Croatia under Ottoman Empire ${ }^{20}$ we can safely say that the history of Ottoman Lika is still waiting for a detailed scientific study.

\section{ESTABLISHMENT OF OTTOMAN RULE IN LIKA, MILITARY- ADMINISTRATIVE AND JUDICIAL ORGANIZATION}

The akıncıs were present in Lika even before the fall of Bosnia in $1463 .^{21}$ Their intrusions were initially sporadic, while following the conquest of Bosnia and organisation of the sancâk of Bosnia they assumed the characteristics of multiple annual destructive attacks which triggered migration waves and ultimately led to demographic and economic devastation of area. The battle of Krbava in 1493 is in Croatian historiography usually considered the peak of the troubles even though

\footnotetext{
16 Moačanin, "Naseljenost Like," 61-65; Moačanin, "Ime Gospić," 51-54.

17 Marko Šarić, "Društveni odnosi i previranja u sandžaku Lika - Krka u 16. i početkom 17. stoljeća," in Diplomska radionica prof. dr. Drage Roksandića, eds. Drago Roksandić et al. (Zagreb: Zavod za hrvatsku povijest, 1999), 67-130; Šarić, “Osmanski korijeni Gospića," 215-248.

18 Stjepan Pavičić, "Seobe i naselja u Lici," Zbornik za narodni život i običaje južnih Slavena 41 (1962): 99-139, 151-171.

19 Milan Kruhek, “Turske utvrde i kule u Lici i Krbavi 1527.-1689. godine," Senjski zbornik 40 (2013): $471-508$.

20 Nenad Moačanin, Turska Hrvatska. Hrvatipod vlašcu Osmanskoga Carstvo do 1791. Preispitivanja (Zagreb: Matica hrvatska 1999), 64-74; Željko Holjevac and Nenad Moačanin, Hrvatskoslavonska Vojna krajina u ranome novom vijeku i Hrvati pod vlašću Osmanskoga Carstva u ranome novome vijeku (Zagreb: Leykam International, 2007), 108-177.

21 Ottoman presence around Otočac was recorded in 1445. Ive Mažuran, Hrvati i Osmansko Carstvo (Zagreb: Golden marketing 1998), 29.
} 
severely destructive incursions continued following the Ottoman conquest of Knin and Skradin in 1522. ${ }^{22}$ At the time when the Bosnian sancâkbeyi Gâzî Hüsrev Bey conquered Udbina, Komić and Mrsinj in 1527, the akınc incursions have already been going on for some sixty years. In that period the population grew scarce and the previous system of counties was dismantled. ${ }^{23}$ Out of the ten counties whose existence was recorded in late Middle Ages under the administration of the Kingdom of Croatia, only Gacka and Brinjska counties remained. ${ }^{24}$ Other parts of Lika and Krbava came under more or less strict rule of the Ottoman Empire. Although there is no direct confirmation in historical sources, it is presumed that the Ottomans conquered Lika the same year as Krbava. ${ }^{25}$ The Ottomans have initially decided to append all newly conquered areas between Una and Velebit, together with the parts between Cetina and Zrmanja which were conquered earlier (Karin, Korlat, Ostrovica, Skradin, Knin, Sinj) to the neighbouring sancâk of Bosnia under temporary military administration as Vilâyet-i Hırvat ${ }^{26}$ governed by voyvoda or subaşı. Following their conquest of Klis, the last town of the Kingdom of Croatia south of Velebit in 1537, the Ottomans have rounded off the territory and established the sancâk of Klis, with Lika and Krbava being its component parts.

The sancâk of Klis was territorially wide and it encompassed territories north of Dinara, namely south-western Bosnia. The fist sancâkbeyi of the sancâk of Klis was Murad Bey. ${ }^{27}$ Parts of Lika and Krbava remained within the sancâk of Klis until 1580, when the territory west of Krka river was militarily and administratively separated from the sancâk of Klis and appended to the newly established sancâk of

22 Moačanin, Turska Hrvatska, 17; Šabanović, Bosanski pašaluk, 56.

23 During late Middle Ages there were about ten parishes on the present-day territory of Lika: Lika, Gacka, Krbava, Brinje, Buško, Hotuča, Lapac, Nebljuš, Odorjan and Una. Lika parish stretched along the river of the same name in Ličko polje; Željko Holjevac, "Ličko-krbavska županija u identitetu Like," in Identitet Like: korijeni i razvitak, ed. Željko Holjevac (Zagreb - Gospić: Institut društvenih znanosti Ivo Pilar - Područni centar Gospić, 2009), 429.

24 For the purpose of organisation of defence again Ottoman attacks until the beginning of $1540 \mathrm{~s}$ Otočac captaincy was established on the Gacka territory, while the Brinje region was appended to the Senj captaincy established in 1469. Both Senje and Otočac captaincies comprised Primorska Krajina with Senj as its center. Primorska Krajina was, in turn, part of the Karlovac Generalate, a component part of Military Frontier in Croatia and Slavonia. Holjevac, "Ličko-krbavska županija," 430.

25 For the assumption that the conquest might have happened in 1528 see: Šabanović, Bosanski pašaluk, 73; Šarić, "Osmanski korijen Gospića," 221.

26 The term was first used in the census of 1528-30 which contains a reference on the presence of Croatian ethnic element in the said area, as well as a reference that the area previously belonged to the Kingdom of Croatia. TD 164, 366-368.

27 The dominant historiographical belief was that the first sancâkbeyi of Klis was Tardić from the Šibenik area, while the most recent research of the Šibenik archival material by Kristian Juran established that his last name was Gajdić. Kristijan Juran, "O podrijetlu i šibenskoj rodbini prvoga kliškog sandžakbega Murat-bega Gajdića," Prilozi za orijentalnu filologiju 66 (2016): 231-239. 
Krka. ${ }^{28}$ The new sancâk encompassed area west and north-west of the Krka river, including Lika and Krbava all the way to the border with the territory governed by the Habsburg Monarchy, as well as the territory of Bukovica and Ravni Kotari all the way to Dalmatia which was under Venetian rule. This sancâk is in the historical sources sometimes referred to as the sancâk of Lika, as well, which means that during the Ottoman rule the toponym Lika covered the territory of the entire sancâk (and was used interchangeably in administrative sense with the official title the sancâk of Krka) which in turn testifies to the importance of the Lika component in the management of the sancâk. ${ }^{29}$ However, Ottoman documents record the term Lika as also synonymous of Ličko polje (Lika sabrâsi) and the surrounding area, namely the territory of the former Lika county now under Ottoman rule (Lika nâhiyesi).

Organisation of the new sancâk should be interpreted within the context of the government's planned settlement of Lika and Krbava and Ottoman efforts to improve demographic, military and economic potential of the entire western serhad for the purpose of establishing Ottoman defence against Croatia and the Slavonian military border, especially after Karlovac was built in 1579. The sancâk of Krka/Lika became a part of the eyalet of Bosnia established in 1580 as the highest military and administrative unit of the Ottoman Empire on the territory of Croatia and Bosnia. The first sancâkbeyi of Krka was most likely Mehmed Bey, a progenitor of the famous Memibegović family, while Idris Bey was the second. ${ }^{30}$ Even though the official seat of the sancâk of Krka/Lika was in Knin or Udbina, ${ }^{31}$ sancâkbeyis often spent time in Ribnik in Lika, especially at the beginning of the $17^{\text {th }}$ century as they had their çiftliks in and around Ribnik. Thus, for example, sancâkbeyi Halil Bey stayed in Ribnik during the rebellion of the Ribnik Vlachs in 1609 when the rebels imprisoned the sancâkbeyi in the Ribnik fort from which he escaped to Banja Luka. ${ }^{32}$ Ottoman tax register from

$28 \quad$ Although there are some doubts in literature about the year of establishment of the sancâk of Krka since there is some evidence showing it was established even before 1580, and then abolished (according to the statements of Ottoman annalist İbrahim Peçevi), following the research of Hazim Šabanović a generally accepted year was given. See: Ibrahim Alajbegović Pečevija. Historija 1520-1576. Volume 1, translated by Fehim Nametak (Sarajevo: El Kalem 2000), 173; Stjepan Antoljak, "Kada i koliko puta je osnivan Krčki ili Lički sandžak?," Zadarska revija 2 (1957): 160166; Šabanović, Bosanskipašaluk, 73-76.

29 Šabanović, Bosanski pašaluk, 75; Batinić, "Njekoliko priloga," 142; Rački, "Prilozi za geografskostatistički opis," 182.

30 Memibegović family got its last name after a hypochoristic Memi (from Mehmet). Mehmet Bey or Memi Bey was the sancâkbeyi of Krka for two years. In October 1582 he was relieved of duty due to Venetian complaints. He was replaced by Idris Bey. Mehmet Bey spent some time as the sancâkbeyi of a temporary sancâk of Krupa, when he left for Hungary to become the sancâkbeyi of Ostrogon. For Mehmet Bey and Halil Bey Memibegović see: Nedim Zahirović, "Tragom jedne karijere: Halil-beg (Halil-paša) Memibegović od Like preko Jegra do Banja Luke," Historijski zbornik LXX, no. 2 (2017), 354.

31 Šabanović, Bosanski pašaluk, 76.

32 Šarić, "Društveni odnosi u sandžaku Krka-Lika," 115-116; Rudolf Horvat, Lika i Krbava. Povijesne slike, crtice i bilješke (Zagreb: Izdanje Matice Hrvatske, 1941), 14. 
1604 tells us that the Halil Bey's çftlik comprised the mezra'as of Budak, Drenovica (or by other name Vukšić), Podkovač, and some other mezráas in the nâbiye of Novi, while Mehmed Bey zaim (which we identify as the first sancâkbeyi of Krka) and Ahmed zaim had their çiftliks in the village of Lovina and on the Lovinac mezraia. In the nâbiye of Novi Ibrahim Bey ${ }^{33}$ had his şiftlik, while, according to the 1574 and 1585 register, Behlul Bey zaim ${ }^{34}$ had, among others, his çiftlik in the field near the Ribnik fort. The title bey points to the fact that both Ibrahim Bey and Behlul Bey served as sancâkbeyis.

Judicially and administratively Lika and Krbava were under the authority of the kadı of the kadılık of Skradin with a seat in Skradin. Next, Ottoman sources name Krka or the kadilık of Knin. ${ }^{35}$ The kadilık of Krka or the kadilık of Knin are two terms for the same judicial seat in Knin competent for all areas west of the Krka river, excepting Ravni kotari which had a separate $k a d \imath$ with a seat in Zemunik. ${ }^{36} \mathrm{In}$ addition to the two documents kept in the State Archives in Venice there is also a direct mention of a kadı in Lika who has, concurrently with the kadı of Zemunik, signed some documents translated into Italian for the purposes of Venetian authorities. ${ }^{37}$ The $k a d \imath$ of Lika could be identical with the kadı of Krka or Knin since the sancâk was termed Krka or Lika, the title potentially referring to $k a d \imath l \imath k$, as well.

\section{LIKA AND KRBAVA IN OTTOMAN REGISTERS FROM THE FIRST HALF OF THE $16^{\text {TH }}$ CENTURY: MILITARY STATUS, DEMOGRAPHIC AND LANDHOLDING STRUCTURE}

Three strategically important forts in Krbava and Lika - Udbina, Novi and Bilaj - were rebuilt by the Ottomans immediately following the conquest and permanent garrisons were placed in them. ${ }^{38}$ They have most likely tried to deploy soldiers in the

\footnotetext{
TD 13/119, 310-313.
}

34 TD 533, 646; TD 622, 482/A.

35 According to H. Šabanović Krka kadiluk was first mentioned in Ottoman sources in 1591, while A. Jakovljević and N. Isailović claim it was in 1583. See: Šabanović, Bosanski pašaluk, 226; Aleksandar Jakovljević - Neven Isailović, Petrovo polje u vrelima osmanskog razdoblja (1528.1604.) (Šibenik: Državni arhiv u Šibeniku, Javna ustanova Nacionalni park Krka, 2019), 172173.

36 According to H. Šabanović this kadılık was first mentioned in the Ottoman sources in the 1640s, while A. Jakovljevića and N. Isailović claim it was in 1577. This means that there were two kadis on the territory west of the Krka river, one for the Kotari, and the other for the remaining part of the sancâk of Krka. See: Šabanović, Bosanski pašaluk, 227; Jakovljević - Isailović, Petrovo polje u vrelima osmanskog razdoblja, 172-173.

37 Jakovljević - Isailović, Petrovo polje u vrelima osmanskog razdoblja, 173.

38 Western sources also report on the reconstruction of Udbina, Novi and Bilaj. The destiny of Mrsinj remains unclear. According to western sources it was reconstructed by ruler of the sancâk of Hercegovina İbrahim Bey, however Ottoman sources currently do not confirm that the Ottomans have assigned it a garrison. Horvat, Lika i Krbava, 12. 
Bunić fort mentioned in a detailed register from 1528-30 as well, but failed..$^{39}$ Other towns from the pre-Ottoman period, such as Komić, Vranik, Podlapac, Kukovac, Radavac and Zelengrad remained derelict or were deserted altogether, Gračac including. ${ }^{40}$ The first Ottoman source which confirms the presence of Ottoman soldiers (nefer) in the towns of Lika and Krbava is the synoptic (icmâl) defter from 1528-1530 which gives a list of forts and their garrisons in the sancâk of Bosnia. ${ }^{41}$ The sources clearly state that the Ottomans have awarded the central military and defence role on the territory of western serhad to Udbina. At the time there were 107 uluffeciya $n^{42}$ soldiers in Udbina. Those were soldiers paid in cash for their military service. The Imperial Treasury paid the nefers of Udbina 473 akçe, which amounted to 170.980 akçe on the annual basis, a considerable sum. The size of the garrisons and a princely sum the state awarded to nefers of Udbina testifies not only to the importance of Udbina for the defence of Krbava, but also reveals general military and strategic plans of the Sublime Porte in the western serhad. In Novi (or Novigrad as it was occasionally referred to in the Ottoman registers), which protected Lika, there were 73 ulûfeciyân whose service was paid for from the Imperial Treasury at 316 akçe per diem, or 111.864 akge per annum. The Ottomans had fiftyfive soldiers in Bilaj at 247 akģe per diem, or 86.436 akçe per annum. In 1530 the Ottomans had the total of 235 paid soldiers in Lika and Krbava whose service cost them 369.280 akçe. ${ }^{43}$ All of the nefers belonged to the ranks of the mustahfiz or fort keepers, while other branches of the military service were not formed as yet. In this early period of the establishment of the Ottoman rule occupying key towns, manning them with guards and fortifying them was of prime importance, because that kept transport routes towards Knin and the Ottoman maritime port of Obrovac well protected. The Ottomans have subsequently placed operational military ranks in those forts (azaps and martoloses as mobile infantry, and fârises as light cavalry) which were necessary for further raids toward Senj and Otočac captaincies and for the successful waging of the "small war" at the border, while they distributed artillery (topcuyân) in the forts following frequent attacks which required firmer defence. However, considering that tax registers from the first half of the $16^{\text {th }}$ century mention the harâmîbâş and the beşlü as owners of individual plots of land in Lika and in Krbava this proves that squads of the harâmîs and the beşlüyân were present in the above mentioned forts before the middle of the $16^{\text {th }}$ century. ${ }^{44}$

\footnotetext{
39 TD 157, 1082. According to western sources Bunić was rebuilt in the middle of the $16^{\text {th }}$ century. Pavičić, Seobe i naselja, 131.

40 TD 284, 23, 231, 402.; Spaho et al., Opširni popis Kliškog sandžaka iz 1550. godine, 22, 234, 413.

41 MAD 540, 218.

42 From ulûfe- wages.

43 MAD 540, 218.

44 TD 284, 418, 420.
} 
The area which falls within the scope of this research was in the first Ottoman register listed as Lika nâbiyesi. The nâbiye of Lika then encompassed all conquered territories from the Gračac fort to the Novi fort, that is to say, from the frontier which separated the territory of the Ottoman Empire from the territory of the Kingdom of Croatia. Under the title of the nâhiye of Lika some other conquered areas in Krbava were listed as well, which were governed by the Ottomans from Udbina, although the register mentions Korbava nâhiyesi. Ottoman rule in Lika was established with great difficulty, primarily due to sparsity of population. Depopulation was massive. The synoptic register (icmâl) from 1528-30 reads in one place that "the nâbiye of Lika is empty space" (Nâbiye-i Lika alân hâlî dir). ${ }^{45} \mathrm{In}$ numerous places in the same source Lika is listed as nâbiye which is in dâr ül-harb, ${ }^{46}$ "in the house of war," "in war territory" even though forts of Novi and Bilaj were firmly under Ottoman control. ${ }^{47}$ The detailed register from 1528-30 describes numerous mezra'as in Lika, as horrible places (mahûfyerler) related (mutasil) to dâr ül-harb. ${ }^{48}$ Thus it is stressed that the area has become a part of the Empire through conquest and that it borders with a country ruled by non-Muslims. Also stressed was the military and political reality of frequent intrusions of Croatian forces from the Senj and Otočac captaincies, as well as from Bihać as a result of which the Empire could not guarantee the safety of Muslims and zimmîs ${ }^{49}$ or secure permanent revenue required for the functioning of the Ottoman sipâhît-timâr system.

In 1530 about 40 mezra'as were recorded in the nâbiye of Lika. ${ }^{50}$ No settlement was recorded as a village (karye). Of the total of about 40 mezraias 17 were inhabited, with the total of 127 tax units (hâne) 106 of them held by Christians, 15 held by Muslims, and 6 held by single individuals (mücerred).

More densely populated mezra'as were Mahovci, Moročani and Mazine (16 Christian households or tax units called hâne, 1 single individual and 2 Muslim households), Papraćani (16 Christian households or hâne, 2 Muslim households), Poljice (2 Muslim households, 13 non-Muslim households), Bukovljani (1 Muslim household, 1 single individual and 14 non-Muslim households), Morovi (13 Christian households, 1 Muslim household), Podstražno (9 Christian households, 1 Muslim household, 1 single individual), Nova Vast (9 Christian households),

\footnotetext{
TD 164, 47.

TD 164, 367.

TD 164, 2, 47.

48 TD 157, 1080-1081.

49 Zimmî - subject of the Ottoman empire paying poll taxt, non-Muslim.

50 In Ottoman tax terminology mezra'a was an abandoned or depopulated village. Even though they were deserted, mezraias had visible remnants of earlier settlements, such as houses, wells and other infrastructure used by previous inhabitants. Also, those could have been areas that the inhabitants of the neighbouring villages used for agriculture.
} 
while the following mezra'as were sparsely populated: Čelopek (8 Christian households), Bisić (4 Muslims, 2 single men), Dugošani (5 Christian households, 1 single, 1 Muslim), Lovine (5 Christian households), Zapujani (1 Christian household, 1 Muslim household), Zabužani (4 Christian households), Četenić (4 Christian households), Kožile (4 Christian households). ${ }^{51}$ For certain mezráas such as Kožile, Dugošani, Zapujani, Bukovljani, Nova Vast the records state that they were populated by Vlachs (Eflâkân). ${ }^{52}$

The Ottoman authorities have turned large parts of vacant land into agricultural land given up for lease, namely into çiftiks, which were leased out to interested individuals for fixed low amounts. ${ }^{53}$ In the years 1528-30 there were eight çiftliks in Lika and Krbava. The following people appear in registers as çiftlik holders: 1) Voyvoda Sinân, ${ }^{54}$ from the entourage of the former Bosnian sancâkbeyi Yûnus paşa $5^{55}$ 2) Voyvoda Dragoje, Dragiša and beşlü Ali; ${ }^{56} 3$ ) Turahân, son of Karagöz and Petar, son of Vukša ; ${ }^{57}$ 4) Yahyâ, son of İsmail, Dragić, son of Dragiša and Radoje; ;8 5) beşlü Hasan and beşlü Temurhân; ${ }^{59}$ 6) Hasan and Dâvud; ${ }^{60}$ 7) beşlü Hasan, çavuş Hüseyin, Ferhâd Lugić and a few other interested individuals; ${ }^{61}$ 8) Petar Gučić. ${ }^{62}$

From the revenue from the lease of çiftliks and the farming of mezra'as Ottoman Empire could only partially cover the cost of four military endowments or timârs which had the following registered owners: Ca'fer, son of Udovičić, knez Čulin,

51 Names of villages and mezraias are herein written without question mark if a toponym has been located or its reading determined beyond doubt irrespective of the fact that it cannot be located today. Question mark is used next to toponyms for which there is any number of possible readings, and it has not been possible to determine which of those is the correct one. In resolving the issues with toponyms I have used the works of Stjepan Pavičić and Ivica Mataija.

52 TD 157, $1077-1078$.

53 For çiftiks as mezráas given up for lease for small amounts of money in unsafe frontier areas see: Moačanin, Turska Hrvatska, 126.

54 Voyvoda Sinan's çiftik encompassed the territory between the destroyed forts of Vranik and Komić, and villages of Gornji and Donji Smokrići, Podal and Namlina (?). The estimated income from that çftlik was part of the knez Čulin's timâr and it amounted to 750 akçe. The source does not give information on permanent residents of the çiftlik. TD 164, 364.

55 Yûnus-paşa was Bosnian sancâkbeyi from 1512 until 1513, and from 1514 until 1515.

56 Their çiftlik encompassed the territory of mezraia around Gračac, near the destroyed forts of Radavac and Zelengrad. TD 157, 1081.

57 Their çiftlik encompassed the territory of mezra'a Trnovljani and Mioćani in Lika. TD 157, 1081.

58 The çiftlik encompassed mezra Projani (?) and the lands of Juraj Sudac (judge?). TD 157, 1081.

59 The çiftlik encompassed Veliko and Malo Podkrbavje and Pećani near Udbina in Vilayet-i Hırvat. TD 157, 1082.

60 The çiftlik encompassed summer pasture Mazine near Udbina. TD 157, 1082.

${ }^{61}$ For their çftlik it was specified that it is situated in the Vilayet-i Hirvat, covering numerous mezra'as near fort Bunić and fort Komić. TD 157, 1082.

62 His çiftlik encompassed mezra'as Gospina Gorica and Jošane in Krbava. TD 157, 1083. 
knez Vukašin, son of Sladoje and Petar Preić. In addition to the uncertain revenue from mezra'as and çiftliks all over Lika and Krbava, some of them had revenue from the estates situated deeper in the sancâk of Bosnia, in safer areas. To others yet the Sublime Porte gave a monetary supplement to the basic revenue received from Lika and Krbava endowments which speaks of the level of demographic and economic devastation of that space.

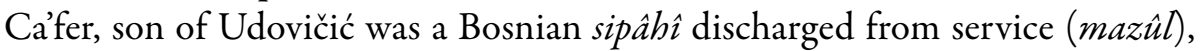
or "waiting" for new service. His family also had endowments in the nâhiyes of Sinj, Cetina and Vrlika. ${ }^{63}$ His timâr in Lika encompassed 14 inhabited mezra'as: Moročani, Mahovci, Mazine, Poljice, Lovine, Zabužani, Čelopek, Četenić, Nova Vast, Kožile, Bisić, Dugošani, Zapujani and Bukovljani. These mezra'as were farmed because the register gives figures of production levels, and the total estimated revenue of these mezraás was 6.475 akçe. ${ }^{64}$ There were 11 Muslim households, 5 single individuals and 73 non-Muslim households in those mezra'as. In addition to these, Ca'fer had a more reliable source of revenue through a levy from military village of Poljanica (or Bilosalić) in the nâbiye of the Saraj in Bosnia, with 14 Muslim households, one non-Muslim household and three one-person households. ${ }^{65}$

Revenue from timâr of knez Vukašin, son of Sladoje came from mezra'as in Papraćani, Morova and Podstražno and amounted to 995 akçe. Sublime Porte added 1.295 akçe to this amount to form a smaller timâr. The three mezraias had 33 Christian households or hâne, 4 Muslim households and one single individual household. ${ }^{66}$ Ottoman policy of granting timârs to Vlach knezes who were thus incentivised to settle their Vlach communities or cemâats in the vacant areas can be traced to the earliest days of control over the said territory.

Another discharged Bosnian sipâhî became a holder of timâr - Petar Preić. His timâr encompassed numerous mezra'as and a few çiftliks in Lika and Krbava, as well as in the neighbouring nâbiyes of Zrmanja, Popina, Ostrovica and Srb. His endowment in Lika included mezráa Morovi assigned to Sladoje and Orthodox priest ( $p \circ p)$ Vukašin, zemin of the varoß̧ of fort Gračac, mezra'as Mahori, Purišani, Nadgorica (Jadgodica?) and Zapotočani which were assigned to Ca’afer, "mezra'a of the nâhiyes of Lika" assigned to Nikola Bedović, mezra'a Podribnica(?) and Mendova (Medova - Medak?) assigned to Pavle and Radivoje, mezráa Zrnić assigned to Ivaniš, mezráa Novosel near the Gračac fort assigned to Vuk Grujac,

\footnotetext{
63 Another member of the Udovičić family, Hasan, most likely brother to the above mentioned Ca'fer, had holdings in the nâhiyes of Neretva and Visoko. See: Fazileta Hafizović, "Posjedi zvaničnika i njihovih porodica u Kliškom sandžaku u 16. stoljeću," Znakovi vremena 13/48- 49 (summer-autumn 2010), 256.

64 TD 164, 366.

65 TD 164,366

66 TD 164,367
} 
çiftlik hold by knez Dragoja and Dragiša, çiftlik hold by Turahân, son of Karagöz, and Petar, son of Vukša, çiftlik hold by Yâhya, son of İsmail and Dragić, son of Dragiša and Radoje, mezráa Gudušić (Godušić), Gaćepeći and Lišić assigned to tailor Hüseyin, mezra Zrninica assigned to Grgur, mezra'a Kolunić assigned to Obrad, mezra Borslatković assigned to Koca Mahmûd, mezra’a Gradičina Podvrbče (Pod Vrebac?) assigned to Dervîş Behrâm and his brother, mezra'a Kukovac Varoš assigned to Ca'fer bey Udovičić, mezra'a Lovinac assigned to Mehmed Ağa, mezra'a Ban Dol assigned to İskender.

Petar Preićs endowment included çiftlik of beşlü Hasan and beşlü Temurhân in the Hirvat vilâyeti, çiftlik of Hasan and Dâvud near Udbina, çiftlik of beşlü Hasan, çavuş Hüseyin and Ferhâd Lugić in Krbava, mezra'as Duga Vas and Korita in Krbava assigned to Blaž Trgočić, and çiftlik of Petar Gučić which encompassed mezráas of Gospina Gorica and Jošane.

Landholdings in Lika and Krbava yielded little revenue, the total of 1.725 akçe (mezra'a Lovinac yielded the most, 285 akçe). The source does not give information about permanent residents of mezra'as and çiftiks which were part of Petar Prejić's endowment (it states that they are situated on dangerous territory and that they cannot be farmed, thus fixed low revenue amounts are given). ${ }^{67}$ The total amount of revenue from all of his landholdings was 3.908 akçe. ${ }^{68}$ The government paid out a monetary supplement to this low timâr, undoubtedly to motivate the colonisation of Lika.

Even a glance at the names of the individuals who were assigned mezra'as and çiftliks in Lika in this earliest period of Ottoman rule, as well as a glance at the names of taxpayers who inhabited the mezra'as, reveals that ethnic and religious affiliation was multifarious. There were Muslims and Christians, mostly new immigrants. Yet there were autochthonous inhabitants left as well, which can be deduced from their names such as Ivaniš, Grgur and Blaž which are listed as tenants of mezra'as. Additionally, in some mezra'as Vlachs were predominant.

The register of 1550 testifies to the fact that the demographic and military situation in the nâbiyes of Lika was not stable even twenty years on. Localities marked as mezra'as now exceed fifty in number, and much more are now described as dangerous places which cannot be farmed which is the reason for their abandonment. Such examples are mezráas Gudušić (Godušić), Gaćepeći and Lišićc ${ }^{69}$,

TD 164, 367-368. In addition to the above mentioned, Petar Preić's endowment comprised of mezra'a Hotešić in Zrmanja assigned to knez Lazar, mezra'a Obrenić in Popina assigned to Karağöz, mezráa Čutnić in Srb assigned to Kara Ca'afer, as well as five çiftliks in the nâhiyes of Saraj and Dubrovnik.

68 TD 164, 367-368.

69 TD 284, 231; Spaho et al, Opširni popis Kliškog sandžaka iz 1550. godine, 235. 
Morovi and Smojčina near Gračac ${ }^{70}, Z_{\text {rnić }}{ }^{71}$, mezráas Trivljani and Misoćani ${ }^{72}$, priest ( $p \circ p$ ) Stepan's mezra'a near Gračac used by Vuk, Cvetko and Radovan ${ }^{73}$, çiftlik of Yâhya, son of İsmail, Dragić, son of Dragiša, Radojina, son of Brajko and Vukić, son of Vukosav which comprised mezra'a Projani (?) near Novi which was previously owned by Juraj Sudac (judge?) and mezra' $a$ Krbava and the land hold by Juraj, son of Vukša ${ }^{74}$, mezra'a Gradičina Podvrbče (Pod Vrebac?) hold by Derviş Behrâm and his brother 'Alî̀ , mezra'a Dubnić hold by Kara Ca'afer and Kurd'76, mezra'a Borslatković owned by Koca Mahmûd ${ }^{77}$, çiftlik of beşlü Hasan, Temurhân and İskender which comprised mezra'as Malo and Veliko Podkrbavje and Pećani ${ }^{78}$, mezráas Podribnica (?) and Mendova (Medova - Medak?), ${ }^{79}$ mezráas Zrnica, Podmijača and Trnova Mala which were owned by a few Christians, ${ }^{80}$ etc.

There are numerous references in the register that reaya ${ }^{81}$ in Lika changed sides or inhabited a different place. Thus for example, reaya left mezráas Bukovljani, ${ }^{82}$ Dugošani, ${ }^{83}$ Ravna Popina ${ }^{84}$ mezra'a Bisić known as the land of Grgur Milaković, ${ }^{85}$ Lovina, Lovinac and Podžirje, ${ }^{86}$ Kožilii, ${ }^{87}$ Zapujani, ${ }^{88}$ etc. Such notes of the census takers point to the conclusion that, even though population was sparse in the ini-

70 TD 284, 235; Spaho et al, Opsirni popis Kliškog sandžaka iz 1550. godine, 234 -235.

71 TD 284, 251; Spaho et al, Opširni popis Kliškog sandžaka iz 1550. godine, 257.

72 Which were çiftlik of Temurhân, son of Karagöz, Petar, son of Vukašin, Vukdrag, son of Juraj, Petko and Stepko. TD 284, 392; Spaho et al, Opširni popis Kliškog sandžaka iz 1550. godine, 404.

73 TD 284, 394; Spaho et al, Opširni popis Kliškog sandžaka iz 1550. godine, 406.

74 TD 284, 396; Spaho et al, Opširni popis Kliškog sandžaka iz 1550. godine, 407.

75 TD 284, 401; Spaho et al, Opširni popis Kliškog sandžaka iz 1550. godine, 412.

76 TD 284, 414; Spaho et al, Opširni popis Kliškog sandžaka iz 1550. godine, 425.

77 TD 284, 415; Spaho et al, Opširni popis Kliškog sandžaka iz 1550. godine, 425.

78 TD 284, 420; Spaho et al, Opširni popis Kliškog sandžaka iz 1550. godine, 429.

79 TD 284, 400; Spaho et al, Opširni popis Klišog sandžaka iz 1550. godine, 411.

80 TD 284, 419; Spaho et al, Opširni popis Klišog sandžaka iz 1550. godine, 429.

81 Subjects of the Ottoman Empire who paid taxes and primarily farmed the land.

82 According to the census taker's note this mezra'a previously had 6 households of reaya, but they have left their place of residence and have settled elsewhere. TD 284, 399; Spaho et al, Opsirni popis Kliškog sandžaka iz 1550. godine, 410.

83 TD 284, 231; Spaho et al, Opširni popis Kliškog sandžaka iz 1550. godine, 235.

84 There were 3 Christian households recorded there before. Spaho et al, Opsirni popis Kliškog sandžaka iz 1550. godine, 370.

85 TD 284, 379; Spaho et al, Opširni popis Kliškog sandžaka iz 1550. godine, 392.

86 In mezra'as Lovine, Lovinac and Podžirje at the time of the census there was no one, even though earlier records show 5 inhabitants. TD 284, 396; Spaho et al, Opširni popis Kliškog sandžaka iz 1550. godine, 408. TD 284, 396.

87 Earlier records show 4 inhabitants, but they all ran away. TD 284, 407; Spaho et al, Opširni popis Kliškog sandžaka iz 1550. godine, 418.

${ }_{88}$ Earlier records show two persons living there. TD 284,408; Spaho et al, Opširni popis Kliškog sandžaka iz 1550. godine, 419. 
tial period of the Ottoman rule, Lika still had a larger population in 1530 than in 1550. Migration from the Ottoman to the Habsburg and Venetian territory began already in 1530s and continued for the rest of the $16^{\text {th }}$ and throughout the $17^{\text {th }} \mathrm{cen}$ turies. There was a number of reasons for it, but the most important was constant insecurity. Devastating invasions of uskoks near Senj which began after 1537 drove away the remaining inhabitants which left their different ways; some to the area controlled by the Habsburgs, other deeper into the Ottoman inland, others yet into the Venetian Dalmatia and Istria. Udbina, Novi and Bilaj forts have also been attacked multiple times. ${ }^{89}$

Plots in Lika that had once been farmed, but were by the middle of the $16^{\text {th }}$ century abandoned were used by transhumance pastoralists (hâymâneler) as summer pastures. The government has therefore decided to start collecting fees for grazing on such plots. For example, from the areas of the devastated forts of Komić, Vranik and Podlapac the government collected revenue for grazing in the amount of 1.500 akçe. ${ }^{90}$ Mezra'a Otrić in Popina which became the property of Karagöz and Nasûh, sons of 'Abdullâh and has served as a grazing ground of the stock owned by cemấat lead by knez Vukosav, ${ }^{91}$ etc.

Fertile plots were still occasionally being farmed by lease holders. For some mezra'as it was recorded that they are being farmed "from the outside" (such as for example mezra'as Poljice ${ }^{92}$, Nova Vast ${ }^{93}$, Lovine ${ }^{94}$, Četečićc ${ }^{95}$, Čelopek ${ }^{96}$ ) with no mention of the actual holders, while in other cases records state who used the land. For example, a few Christians - Radoje, Bože, Vukašin, Pavko, Vuksan, Đurašin, Milun, Radica, Pribila, Dobrica and Dobrila - inhabitants of the village of Bitelić in the Sinj-Cetina region gave permission to be recorded as users of the land and water mills in mezráas of Morovi and Smojčina near the Gračac fort. ${ }^{97}$ Inhabitants of the village of Bitelić as holders of mezra'as are listed in the records from $1520-30 .{ }^{98}$ Also, transhumance pastoralists from the same village,

89 Western sources report that Udbina was devastated in 1544. Ottoman sources also describe heavy devastation of Udbina in 1570/71. Novi and Bilaj were devastated already in 1530. Pavičić, Seobe i naselja, 129, 130; Mühimme defteri (MD) 12, 224; MD 14, 276.

90 TD 284, 23; Spaho et al, Opširni popis Kliškog sandžaka iz 1550. godine, 22. The government collected income by taking a sheep or its counter value depending on the amount of livestock (25 akçe for a large herd or flock, 15 for the middle-sized one, and 10 for a small one).

91 TD 284, 250; Spaho et. al, Opširni popis Kliškog sandžaka iz 1550. godine, 256.

92 TD 284, 386; Spaho et al, Opširni popis Kliškog sandžaka iz 1550. godine, 398.

93 TD 284, 386; Spaho et al, Opširni popis Kliškog sandžaka iz 1550. godine, 399.

94 TD 284, 392; Spaho et al, Opširni popis Kliškog sandžaka iz 1550. godine, 404.

95 TD 284, 396; Spaho et al, Opširni popis Kliškog sandžaka iz 1550. godine, 408.

96 TD 284, 231; Spaho et al, Opširni popis Kliškog sandžaka iz 1550. godine, 234.

97 TT 284, 231; Spaho et al, Opširni popis Kliškog sandžaka iz 1550. godine, 234 - 235

98 TD $157,1080$. 
both Christians and Muslims - Ca'afer, son of Murâd, Hizır son of priest, Cvetko, son of Dobrila, Radoje, Radojko, Radivoj, Radosav, Vukoje, Radica, Ivan, son of Radica - used the mills and mezra'as of Mahori and Purišani near the fort of Novigrad, and Nadgorica (Jadgodica?), Zapotočani, Podstrana, Papraćani, Plićani, Tomljani, etc., ${ }^{99}$ while the three "new Muslims" (İskender son of Vukosav, Şâhîn son of Radojko and Ahmed son of Miločić) from the village of Radovina near fort Duvno in the sancâk of Herzegovina, used mezra'a Mahdol. ${ }^{100}$ The latter speaks volumes about the origins of migration in the period from 1530s to 1550s, and of the course of Islamization. Listing Eastern Orthodox priest ( $p o p$, from Greek papás - father) reveals that Eastern Orthodox population has immigrated, while listing recently Islamized population immigrating from the sancâk of Herzegovina points to Islamization of Vlachs as well. ${ }^{101}$

Çiftliks were still owned by Muslim soldiers and eminent people in the sancâk who were paying resm-i tâpu to the Imperial Treasury. Thus for example çiftlik which comprised of mezraias Mala and Duga Poljica, Štitar and Mahovci became the property of sipâhî̀ Dîvâne Mustafâ harâmîbâş̧ı and Murâd, son of falconer Mustafâ, after the two have paid 400 akçe into Imperial Treasury ${ }^{102}$; meadow (çayır) Plana near Udbina became a çiftlik of saddle maker Mehmed ${ }^{103}$; Voyvoda Sînân, member of entourage of the former Bosnian sancâkbeyi Yûnus Paşa remained the owner of çftlik comprising mezra'as of Donji and Gornji Smokrići, Podalj and Namlina (?) situated between the destroyed forts of Vranik and Komić, and part of the Ričice mezra'a near Gračac, etc. ${ }^{104}$ And while some Muslim soldiers did reside in the forts and did farm the land leased to them together with their families, eminent individuals from the Ottoman administration undoubtedly did not live in the said çiftliks, and have instead left other interested individuals to farm their land.

\section{SETTLEMENT OF LIKA}

The Ottoman Empire implemented the policy of settlement of Lika in the period 1550 to 1585 in the time of Malkoç Bey Kara Osmanoğlu, the sancâkbeyi of Klis, Ferhâd Bey Sokollu, the sancâkbeyi of Klis and Bosnia and Mehmed Bey, the sancâkbeyi of Krka. The aim of the settlement process was to strengthen Ottoman military positions toward the Primorje captaincy. In 1560 the sultan ordered Ferhâd Bey Sokollu that 70 destroyed forts in the Lika and Krbava nâbiyes near the forts of

\footnotetext{
99 TD 284, 392; Spaho et al, Opširni popis Kliškog sandžaka iz 1550. godine, 404.

100 TD 284, 421; Spaho et al, Opširni popis Kliškog sandžaka iz 1550. godine, 430.

101 Šarić, "Osmanski korijeni Gospića," 230.

102 TD 284, 418; Spaho et al, Opširni popis Kliškog sandžaka iz 1550. godine, 428

103 TD 284, 430; Spaho et al, Opširni popis Kliškog sandžaka iz 1550. godine, 438.

104 TD 284, 430; Spaho et al, Opširni popis Kliškog sandžaka iz 1550. godine, 439.
} 
Gračac and Udbina be settled and revitalized. It was to be executed by giving (not leasing!) the land around the forts suitable for settlement to interested individuals, issuing of the land deed (tâpu) and payment of the tapu resmi (resm-i tâpu) to the state. The order stressed that the agricultural land shall not be given to the stock breeders and çiftlik holders (who do not have a permanent residence), but to those who shall farm the land and live there permanently (reaya). ${ }^{105} \mathrm{~A}$ wave of colonisation in Lika had to have begun even before 1550 because a Spanish source from 1560 states that Malkoç Bey, the sancâkbeyi of Klis had settled 8.000 to 15.000 "Turkish" households in Lika in the past few years. ${ }^{106}$ Ivan Lenković, captain from Senj has in 1551 reported to Habsburg king Ferdinand that "the Turks" have populated the border with the Kingdom of Croatia with a few thousand inland Vlachs with over 100.000 sheep and cattle. ${ }^{107}$ Even though the central government had a good repopulation and re-agrarisation plan for the area, its implementation did not go as planned. And not only because of the "small war" on the border and invasions of the enemy units from Primorje captaincy, but also because of the conflict between earlier lessees and new immigrants. Disputes over the settlement of Lika were recorded in a document dated 1566 when Hüsrev Bey, the sancâkbeyi of Klis, reported to Sublime Porte that some reaya appeared in Bilajsko polje in Lika and became its permanent residents. ${ }^{108} \mathrm{He}$ stressed that the area had been vacant and neglected for thirty years, and the newly settled reaya is prevented from farming the land precisely by those who were listed in tax register under fixed amount (namely, previous lease holders). Unquestionably, the aim of the regional government and the Sublime Porte was to repopulate the vacant area with reaya that would actually live there and reside in Lika. Therefore, the sultan's court ordered that the previous owners not mix with the newcomers who wish to revitalize the derelict forts. It was in the interest of the government to repopulate the area and change the legal status of the existing mezra'as and çiftliks from lease holdings into tithe areas from which the reaya shall give tithe (ösr $)$ and pay usual levies instead of low fixed amounts. However, that was no easy task for regional Ottoman governors as shall become evident form the orders preserved in Mühimme defteri outlined below.

In addition to immigration the government incentivised reconstruction of destroyed forts all over Lika and Krbava. Until mid- $16^{\text {th }}$ century the Ottomans have reconstructed desolate Gračac because the register of 1550 describes it as a fort (kale), with the settlement below it, a varoş whose inhabitants, immigrants from the village of Bitelić near Sinj, farmed the surrounding land (vineyards, gardens

105 MD 3, fol. 338, no. 988 ; Holjevac i Moačanin, Hrvatsko-slavonska, 157.

106 Mirjana Polić-Bobić, "Dva izvještaja o naseljavanju muslimana u Liku i Krbavu," Radovi Zavoda za hrvatsku povijest 24 (1991), 207-210.

107 Pavičić, Seobe i naselja, 131.

108 MD 5, fol. 666, no. 1869. 
and meadows) and worked the mills. ${ }^{109}$ Udbina was flooded in $1569 / 70 .{ }^{110}$ Even though an Ottoman source from 1570 states that Lika and the Novi fort belong to the "House of Islam" (dâr ül-islâm) ${ }^{111}$, insecurity was still great, forts did not have enough manpower or weapons, and intrusions from enemy lines were frequent. ${ }^{12}$

\section{NOVI, MEDAK AND BILAJ BARLETA NÂHIYES IN THE OTTOMAN TAX REGISTER OF 1574: DEMOGRAPHIC AND ECONOMIC STRUCTURE, LANDHOLDING RELATIONS}

The efforts of the Ottoman government to revitalise Lika and Krbava demographically and economically did give some results because the register of the sancâk of Klis from 1574 lists the total of 12 nâhiyes, 7 of which were in Lika (Gračac, forts Novi, Cvituša, Medak, Perušić, fort Zvonigrad, fort Bilaj Barlete), and five in Krbava (fort Udbina, forts Bunić Bilaj, Mazin, Lapac and Nebluh). ${ }^{113}$

The paper shall focus on the three nâbiyes in Lika which are the topic of this research: fort Novi, fort Bilaj Barlete and Medak. ${ }^{114}$

The borders of the nâhiyes of the Bilaj Barlete and Novi forts stretched between the nâbiye of Medak, the derelict Ostrovica fort in Lika, the derelict Smiljan fort, the derelict Stari Grad fort near the Adriatic sea, from the top of the mountain to the derelict Počitelj fort and again down to the border of the nâbiye of Medak. ${ }^{115}$ The borders of the nâbiye of Medak stretched from the Zir mountain along the border of the nâbiye of Cvituša to the derelict Trnovac fort, from the top of the mountain to the derelict Počitelj fort, along the border of the nâhiye of Novi fort to the Veliki Mogoric fort, and along the border of the derelict Podlapac fort to the border of the nâbiye of Cvituša. ${ }^{116}$

In the three nâhiyes the total of 37 villages (karye) was registered, 18 of which in the nâbiye of Novi, 5 in the nâbiye of Bilaj Barlete and 14 in the nâbiye of Medak. In the three nâbiyes the total of 20 çiftliks were listed, of which 9 in the nâhiye of Novi, 4 in the nâbiye of Bilaj Barlete, and 7 in the nâbiye of Medak. The nâbiye of

\footnotetext{
109 TD 284, 405; Spaho et al, Opširni popis Kliškog sandžaka iz 1550. godine, 415 - 416.

110 MD 5, fol. 666, no. 1869. MD 9, fol. 53, no. 140.

111 MD 14, fol. 553, no.775

112 It is an order to sancâkbeyi of Klis which describes a coordinated attack of 1.500 enemy soldiers from the direction of Bihać toward Udbina (Bilajsko polje) and about 200 toward Novi. It was that attack that the sancakbbeyi notified the Porte that the forts are without soldiers and weapons. MD 14, fol. 553, no. 775 .

113 TD 533.

114 The register of 1574 also gives the name Medava in few places. Therefore we need to provide for the possibility that this name was used as well although this has not been recorded in the literature so far. TD 533, 367.

115 TD 533, 818.

116 TD 533,790
} 
Novi was the most extensive, and had the greatest number of villages and çiftiks, while Bilaj Barlete was the smallest with a modest number of villages and çiftiks.

The nâbiye of the Novi fort alone according to the register from 1574 was economically and demographically revitalised area when compared to the information from the earlier register. ${ }^{117}$ Near the fort three water mills which have been operational for half a year and which earned the government the revenue of 45 akçe were registered. ${ }^{118}$ In addition to these, the source states that there were two additional water mills in the nâbiye which were derelict ocaklar on the river Barlete and the census taker gave an assessment of 30 akçe that the holding earns the government. ${ }^{119}$ There were quite a few mills in çiftliks, but the exact number is not stated.

The government started charging various levies in the nâbiye: the amount was estimated to the total of 120 akçe. Individual items mentioned were: inland custom tax or market tax on buying and selling of large quantities of goods arriving in horse loads or cart loads (bâc-i siyâh), provisional tax collected to take defendants to court (ihzâriye), market tax collected for supervision and mühtesibs (ibtisâb),

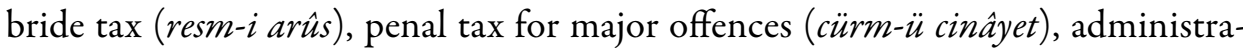
tive tax (niyâbet), fee for agricultural damage (polaçina). ${ }^{120}$ From the above we can infer the following: a) somewhere on the territory of the nâbiye, perhaps in the immediate vicinity of the Novi fort, weekly market activity began (weekly market or market day), b) that the fort was probably a seat of the kadis assistant (naib), c) that there was a court room in the fort, $d$ ) that there was market supervision in the nâhiye (which was a duty of muhtesib or naib) on market day, that customary fees were collected from the traders and craftsmen, that prices were supervised, as well as the accuracy of measurements, etc. e) fines were introduced for offenders, $f$ ) bride tax or a fee to be paid upon the marriage of one's daughter started to be collected, g) agriculture was becoming increasingly important and a fee for protection of crops in the fields, as well as a compensation for the damage to the crops incurred by livestock began to be collected.

As was already mentioned above, there were 9 çiftliks listed in the nâhiye of Novi stretching all across the nâhiye encompassing parts of arable land in the field under the Novi fort, villages and mezra'as near and far, grazing land (otlâk), and summer pastures (yâylâk), water mills and meadows. Fees levied from the çiftliks were part of sipâhîs' timârs. Tithe (össr), a tenth of all crops grown, was collected from two çiftliks. From four çiftliks an amount was given without breakdown per product, while for three çiftliks there are no entries at all. Tax collected for the following ag-

TD 533, 642-646.

118 TD 533, 642.

119 TD 533, 646.

120 TD 533, 642. 
ricultural products has been recorded: wheat, mix (mix of cereals), oat, vegetables from vegetable gardens, hay, flax, beehives, onion, garlic and cabbage. In addition to these traditional crops, çiftliks also grew other cereals (such as buckwheat, rye, etc.), specific climate appropriate fruit and vegetables, but those were not entered in the register by the census taker since the goal was to produce a standardised defter for the sancâk of Klis with basic products essential for the functioning of the sipâhî-timâr system. The quantity of cereal a sipâhî was allowed to collect was expressed in keyl a measuring unit approved for the sancâk of Klis. ${ }^{121}$ In addition to the tithe of the agricultural products, the sipâh î had the right to collect feudal bride tax paid on the marriage of a daughter, fee for agricultural damage and half of $b \hat{a} d-u$ hava. ${ }^{122}$ The above testifies that the çiftliks were inhabited, even though there is no data on the inhabitants.

The following çiftlik holders are listed in the nâbiye of Novi: 1) Mehmed, Mustafâ kethüda and Hüseyin, children of Zeynihân; ${ }^{123}$ 2) Mehmed, Nesûh, the mustahfizes, the beşlüs and the martoloses of the Novi fort; ${ }^{124} 3$ ) Bekir Ağa, the beşlüs and the martoloses of the Novi fort; ${ }^{125} 4$ ) Mehmed leader of the martolos and other martoloses, the beşlüs and the mustahfizes of the Novi fort; ${ }^{126}$ 5) Bekir Ağa, 'Ömer, 'Osman, 'Ali and Hasan, children of Zeynihân; ${ }^{127}$ 6) Bâlî kethüda of the Novi fort and his children Mehmed, Ramazân, İbrahim and Mustafâ; ${ }^{128}$ 7) Bekir Ağa, beşlü of the Novi fort ${ }^{129}$; 8) Behlül Zaim, Mehmed Prko, Feridun Ağa and Yûsuf $h o c a^{130}$; 9) Behlûl Bey Zaim, Oruç kethüda, voyvoda Sînân, Velî Blagajlo, Mehmed Prko (?),

121 Keyl measuring unit for cereals in the sancâk of Klis was 64 okkas.

122 Bâd-u havâ literally means "wind and air". It is a fee for keeping order. Includes petty fines and penalties, the most important being blood money.

123 The çiftlik consisted of parts of zemin field Novi, Pejačić mezra'a (with derelict fort), mezráas Doljani, Gornja and Donja Cvrtina (?), Mahori, Straža, Dalenić with grazing land and summer pasture, water mills and a meadow.

124 The çiftlik consisted of parts of zemin field Novi and mezra'as Poljice, Brušan, Novosel, Strćan Gornji, Bilišan, Dugošan with grazing land, summer pasture and a meadow.

125 The çftlik consisted of parts of zemin field Novi and mezra'as Podhumci, Dugošan, Bilišan, Barećan grazing land, summer pasture and a meadow.

126 The çiftik consisted of parts of zemin field Novi and mezra'as Kolić, Donji and Gornji Radučani, Bilišan, Smiljan, Novosel, zemin of a derelict church with grazing land, summer pasture and a meadow.

127 The çiftlik consisted of parts of zemin field Novi, mezra'as Donji and Gornji Trnavac, Vinarina, Dolina, (?) field near the Bag fort, Konjsko with water mills, grazing land, summer pasture and a meadow.

128 The çiftlik consisted of parts of zemin field Novi, mezra'as Donji and Gornji Zapotočan, grazing land, summer pasture and a meadow.

129 The çiftlik consisted of parts of zemin field of the Novi fort.

130 The çiftlik consisted of parts of zemin field Novi and mezra'as Donja Banova, mezra Podhumac grazing land and summer pasture and a meadow, water mills and fish pond. It yielded 940 akçe, which was the highest amount collected from farming of all çiftliks in the nâbiye of Novi. 
'Ali Bey, son of Velî, Mehmed and other Mehmed Ağa, Ferhâd kethüda, Mustafâ, Ahmed, 'Ömer, 'Ali Bey, Yûsuf hoca, Mehmed Ağa and Mustafâ. ${ }^{131}$

The sources reveal that the çiftliks were mostly assigned to esteemed individuals (their titles are bey, zaim and hoca which indicate persons in high positions in the sancâk), as well as soldiers in the Novi fort and their commanders. ${ }^{132}$

In 1574 in the nâbiye of Novi 18 villages were recorded. For 15 villages in the defter the amounts of tithe for farm products which the government gave to the sipâhî are recorded. This means that sipâhîtimâr system has been introduced in those villages. Therefore, we could call them tithe villages. Those were the following: Gospoja - place of the church (Gospoya -i kilîsâ yerleri) ${ }^{133}$, Komarevo, Račić, Zapotočje, Podstraža, Smiljan, Trnovac, Barećani, Gornji and Donji Ribnić (?), Podhumci, Bilišani, Gornje and Donje Podoštre, Vinari, Stapan. As far as farmsteads and agricultural production is concerned numerous levies on farm products were recorded. It was also done on çiftliks (wheat, mix of cereals, oat, vegetables from gardens, hay, flax, beehives, onion, garlic and cabbage). In addition to the tithe, the government gave the sipâh $\hat{\imath}$ half of bâd-u havâ, bride tax and fee for agricultural damage collected in those villages. The largest tithe was recorded near the village of Gospoja; it was 1.000 akçe, while the smallest one was paid out near the villages of Gornji and Donji Ribnić (?), and it amounted to 200 akçe. ${ }^{134}$ The amount from the village of Gospoja would suggest significant farm activity. No inhabitants were recorded in any of the above villages, however, the amount of tithe was broken down by items (agricultural products) which does suggest that they were in habited after all, at least most of them such as şiftliks. However, the data from the register makes us unable to say anything about the density of population. In addition to tithe villages there were villages for which we do have direct evidence about population density: in those villages baştines are recorded with the amounts of financial counter value of agrarian production, but without breakdown per item. Thus, for example, the Nekorić

131 The çiftlik comprised parts of zemin in the field of the village near the Ribnik fort and peninsula with St. Nicholas church, with water mills, fish pond, grazing land, meadow, and part of the village Pod(?) in the village of Gornja s Gorićem. The fees collected by the Imperial Treasury from this çftlik was 300 akçe. TD 533, 646.

132 Zaim was a sipâhî of higher rank with endowment valued from 20.000 to 100.000 akçe, while the title of the hoca was attributed to an educated person who might have been a religious teacher, or any eminent person performing a legal duty, or was even engaged in commerce. Bey referred to an influential person in the position of sancâkbeyi, namely the military and administrative commander of sancâk. The title of ăga was given to heads of different army troops in forts, while kethüda denoted deputy of different authorities and commanders in the fort. Those were individuals who performed different military duties in the Novi fort.

133 For relationship between the village of Gospoja and the village of Gospić see: Moačanin, "Ime Gospić ," 51-54; Šarić, "Osmanski korijeni Gospića," 239-242.

134 Račić 400 akçe, Zapotočje 600, Podstraža 524, Smiljan 370, Trnovac 420, Barećani 320, Podhumci 620, Bilišani, Gornja and Donja Podoštre 554, Vinari 420. 
village was a place where there was a derelict fort with 4 Christian baştines with a duty in the amount of 640 akģe, while the Novosel village had three Christian and one Muslim baştine and its duty amounted to 640 akçe, as well. The Brusnice village did not have a single baştine recorded, but it yielded 300 akģe to the government in duties. In addition to these villages, about ten other villages marked by a sign

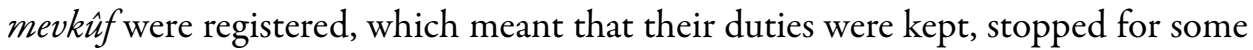
reason, most likely were not directed toward the sipâbî timârs. This refers to the following villages: Brušan (150 akçe), Novasel (200), Donja and Gornja Mahorina (300), Mahori (120), Tatačić (200), the Bag village as a place of a derelict fort (150), Jablanica (220), Ribnik (230), Doljan (200) and Dugošani (220). ${ }^{135}$

Since the nâhiye was situated in the mountainous territory, near Velebit, five summer pastures were registered (Vinara, Konjsko, Rudine, Lapac, Drlesić?) which were also taxed by the government. ${ }^{136}$ Far smaller nâbiye was the Bilaj Barlete fort nâbiye. Only four çiftliks were recorded there, and their holders were: 1) Janko (?) and knez Miloš, son of Ugarko ${ }^{137}$; 2) Mehmed, Mustafâ, Hasan, Halil and 'Abdi Murâd's sons ${ }^{138}$; 3) Murâd Ağa dizdâr of the Bilaj Barlete fort, Hızır, son of Velî, the leader of the martoloses (sermartolos) of the Bilaj Barlete fort and other martoloses and mustahfizes of the Bilaj Barlete fort ${ }^{139}$; 4) 'Ömer, 'Ali and Osmân, sons of Ahmed. ${ }^{140}$ Agrarian production per item was registered only for the çiftlik of Murâd Ağa, dizdâr of the Novi fort and other members of the fort's garrison. Just as in Novi nâbiye, Bilaj Barlete çiftlik holders were eminent men in the nâbiye, such as fort commander and knez, as well as members of the Bilaj Barlete fort garrison. The mustahfizes and the martoloses of the fort were also holders of three water mills on the Barleta river which yielded 45 akçe paid to the government.

In the nâhiye of Bilaj Barlete five villages were recorded, four without data on inhabitants, and with low duty amounts. Those are: Dupčan (100 akçe), Gorica (200), Došlan (? 150), Lika (100)..$^{141}$ Only for the village of Mogorić near the village of Vrbčić it was recorded that it is inhabited, and has 4 Christian baştines which yield the revenue of 640 akçe to the government. ${ }^{142}$ Also, market day was

135 TD 533, 646.

136 TD 533, 646.

137 The çiftlik consisted of a part of the villages Donje and Gornje Barlete with water mills, grazing land, summer pasture and meadow. TD 533, 818.

138 The çiftlik comprised parts of zamin field of the Bilaj Barlete fort, Gorica mezra, part of Srednja Gora mezra'a, part of Sveti Petar zemin with grazing land and summer pasture. TD 533, 818.

139 The çiftlik comprised parts of zemin field of the Bilaj Barlete fort, Dubčani mezra, zemin of St. Peter's church, parts of Srednja Gora mezra'a with grazing land, summer pasture and meadow. Income from çiftlik amounted to 445 akçe. TD 533, 818.

140 The çiftlik consisted of a part of Podrebac (?) mezra' $a$ with grazing land, summer pasture, meadow and water mill. TD 533, 818 .

141 TD 533, 818.

142 TD $533,818$. 
held in the nâbiye, so the government collected customs duties or bac, as well as other taxes and fees from the people, just as it did in the nâhiye of Novi in the total amount of 130 akçe.

In the nâbiye of Medak 7 çftliks were recorded, 14 villages and two mezra'as as one independent tax units. The following individuals are registered as çiftlik holders: 1) kethüda Sînân, Mehmed and Ahmed; ${ }^{143}$ 2) Knez Nikola son of Damjana and knez Radko, son of Vladosav; ${ }^{144}$ 3) Kurd Ağa; ${ }^{145}$ 4) Abdullâh; ${ }^{146}$ 5) Hüseyin, son of Hacci Uveys and Yusûf, son of Kurd; ${ }^{147}$ 6) Mustafâ, Mehmed, Mehmed Ağa, Velî and Mehmed, son of Hüseyin; ${ }^{148} 7$ ) 'Ali, kethüda Ca'fer, Ahmed and Musa. ${ }^{149}$ The government collected the traditional tithe from three çiftliks, while for four other çiftliks only a fixed amount was entered without breakdown per product. Mezra'as Došlan with water mills, Velika and Mala Ribnica (?) were recorded as independent tax units. Velika and Mala Ribnica were held by notary (katib) Hüseyin.

Fourteen localities were registered as villages (karye). No entries for inhabitants were made for three villages: Poljana - place and church of St. Johns, Kupusar and Dubavica. Only the amount of tax debt is recorded for them without any additional explanations. In Počitelj 2 Christian baştines are recorded, two of which are indicated as newcomers (doşlak), Gornja (?) - 4 Christian baştines, Ribnić (?) place and church of St. Lovrinac - 5 Christian baştines and 1 Muslim baştines, Zavrina (?) near Mout Zir - 4 Christian baştines ; Namlina (?) Donja - 2 Christian baştines, Ogorani - 2 Christian baştines, Petrinić - 3 Christian baştines, Lapac - 3 Christian baştines, Veliki Novak - 2 Christian baştines, Mali Novak - one Muslim and one Christian baştines), Novak Selište -2 Christian baştines. The total of 30 baştines were recorded in the nâbiye, 2 of which were Muslim, while 28 were Christian. Even though we do not have information on inhabitants of the remaining villages and çiftiks we can establish that population was scarce. No village had a large number of taxpayers; villages had but a few baştines. Information that the government collected only half of bâd-u havâ and "product" or "crop" from the

143 The çiftlik consisted of parts of the village below Medak fort and part of Podrebac (?) mezra'a with grazing land and summer pasture. TD 533, 790.

144 The çiftlik consisted of the village of Dobro and Račevnić mezra'a with grazing ground, summer pasture and meadow. TD 533, 790.

145 The çiftlik comprised part of the village of Počitelj with summer pasture, grazing land and meadow. TD 533, 791.

146 The çiftlik comprised part of the village of Srijani Gornji with grazing land, pasture and meadow. TD 533, 791.

147 The çiftlik comprised the village of Srijani Donji between the villages of Medava and Kukelj, with grazing land, meadow and water mills. TD 533, 791.

${ }_{148}$ The çiftlik comprised part of the village of Žagar with meadow, grazing land and summer pasture. TD 533, 791.

149 The çftlik comprised Komilić mezra'a with summer pasture, meadow, grazing land and water mills. TD 533, 792 . 
so-called nomads (mahsûl-i hâymâne) expressed in a fixed amount testifies to the fact that those were recent immigrants.

As it has been sparsely populated, planned settlement of Lika continued even after 1574. The order of the Sublime Porte sent to the Bosnian beylerbeyi in November 1581 reveals that the fields - of Lika and of Krbava, have long been vacant and uninhabited, infrastructure destroyed (hâlî ve harâb), for, supposedly, eighty years. However, as a result of the istimâlet ${ }^{150}$ policy and under strictly defined conditions (sartile) reaya has settled in those areas and has started farming them. ${ }^{151}$ These are the years when the Ribnik fort in the nâbiye of Novi was reconstructed and garrisoned so that the soldiers could protect the new immigrants as we have learned from the document dated 16 May 1585 (the source gives names of fârises, while there is no information about other branches of the military). ${ }^{152} \mathrm{New}$ immigrants were supposed to, under the conditions of settlement, remain outside the tax defter, namely, they were not supposed to be registered in it. Also, new immigrants were free from paying cizye for three years. ${ }^{153}$ Tax exemption from the main sharia tax was supposed to be an incentive for colonisation to that population which lived in patriarchal family structures with a larger number of adult males (Vlachs), as well as for landless population used to farming. Even if this meant living on an extremely insecure serhad, exemption from payment of cizye did stimulate colonisation of Lika and incentivise the colonisers to settle on the vacant and abandoned mezra'as. Ottoman sources state that the immigrants arrived from enemy territory, namely from the Habsburg side. ${ }^{154}$ However, many of the new immigrants did not stay in Lika and the sancâk of Krka for a long time, because the Ottoman census taker did distribute the revenue from the population into timârs of the sipâhî and impose the payment of cizye upon colonisation of Lika and as soon as the colonisers began farming which was contrary to the agreement reached with the regional authorities, namely the sancâkbeyi of Krka. ${ }^{155}$ The communication between the

150 The policy of istimalet implied a political strategy of agreement with the Ottomans and their guarantee of certain conditions with non-Muslim population with the aim of establishing, strengthening and stabilising Ottoman rule.

151 MD 46, fol. 232, no. 511; MD 46, fol. 287, no. 657.

152 The order issued by the Sublime Porte to the beylerbeyi of Bosnia based on a letter the sancâkbeyi of Krka sent to the sultan's court informs us that "some time ago" (bundan akdem) reaya settled in Ličko polje, and that for defense and protection of this reaya it would be absolutely necessary to reconstruct the Ribnik fort as it is situated in the important position (mühimm yer). MD 58, fol. $148,388$.

153 Cizye was a tax paid by all adult non-Muslim population fit for work in an Islamic state, it was a "guarantee" of a protected status. Cizye did not have to be paid by priests who lived off collections, the old, the sick, women and children, and those performing some special duty for the state. The amount of cizye changed throughout history.

154 MD 48, fol. 270, no. 769.

155 MD 46, fol. 287, no. 657.; MD 48, fol. 75, no. 210. 
Sublime Porte and the beylerbeyi of Bosnia and the sancâkbeyi of Krka until late 1581 reveal concern that the new immigrants (reaya), which have preserved the area and started farming the field of Lika and other fields in the sancâk of Krka, will spread out and move away again. The sancâkbeyi of Krka notified the Sublime Porte that, should they leave the immigrants out of the register and not collect cizye from them for two to three years, more reaya will arrive, even from the enemy side. ${ }^{156}$ If, however, they do get registered, and their tithe is directed into timârs of the sipâhî, Lika shall become vacant again. ${ }^{157}$ Ottoman sources from the 1580s suggest that some places in Lika became prosperous and densely populated as a result of the Ottoman policy of repopulation and the above mentioned guarantees. In order to keep the population and secure preconditions for colonisation, in January 1582 the Sublime Porte ordered the notary of the sancâk of Klis not to collect cizye from the new immigrants. ${ }^{158}$ Soon the decision on the separation of the Klis and Krka territory was made, and the beylerbeyi of Bosnia was ordered to take a separate census for the sancâk of Krka, namely, to re-register those villages, mezra'as and places in the sancâk that now fell in the Imperial has. ${ }^{159}$ It should definitely be stressed that the policy of guarantees and tax exemption was not uncommon practice in the Ottoman repopulation policy in border territory. For example, in 1568 the Ottomans have settled two hundred households of "infidels from Istria" or Istrian Vlachs from dâr ül-harb near Knin under the provision that each household give the Imperial Treasury 2 filuris per annum, and about thirty akçe to the beys in taxes. They planned to move additional 700 households from the territory around Bihać which then fell under the Kingdom of Croatia and settle them around Obrovac, in the nâhiyes of Podgorje, Karin and Bukovica, and in Lika around Gračac. ${ }^{160}$ This was undoubtedly realised, as the tax register from 1574 testifies. Regional Ottoman authorities invested a lot of effort to recolonise Lika, namely Ličko polje, by the beginning of the $17^{\text {th }}$ century. New immigrants were mostly Vlachs and usually arrived from the sancâks of Klis and Herzegovina and from the neighbouring Bosnian territory across the river Una. Some immigration, however, was also seen from the territory of the Kingdom of Croatia which belonged to the Habsburg Monarchy.

\footnotetext{
156 MD 48, fol. 82, no. 230.

157 MD 48, fol. 75 , no. 210.

158 MD 46, fol. 287, no. 657.

159 MD 48, fol. 163, no. 454.; MD 48, fol. 270, no. 769.

160 MD 7, fol. 901, no. 2468.
} 


\section{NOVI, MEDAK AND BILAJ BARLETE NÂHIYES IN THE OTTOMAN TAX REGISTER OF 1585: DEMOGRAPHIC AND ECONOMIC STRUCTURE, LAND HOLDING}

In 1585 new register was completed. ${ }^{161}$ There were still 7 nâbiyes registered in Lika (Gračac, Zvonigrad, Cvituša, Novi, Medak, Perušić, Bilaj Barlete), while Krbava had 5 nâhiyes (Nebluh, Lapac, Mazin, Udbina, Bilaj Bunić). We shall focus on the changes in the three nâbiyes which are the topic of our study.

In 1585 in the Novi nâbiye there were 7 çiftliks and 18 localities recorded as villages. ${ }^{162}$ The following persons were recorded as çiftlik holders: 1) brother Mehmed Ağa, Hüseyin Ağa and Mustafa kethüda, sons of Zeynihân Ağa; $\left.{ }^{163} 2\right)$ Keyvan kethüda of the mustahfizân at the Novi fort, Nesûh - leader of the artillerymen of the Novi fort, Bâlî kethüda, Memi dede, ${ }^{164}$ Ramadân - leader of a bölük (serbölük), Ferhad 'Ali - serbölük, Bali - mustahfiz of the Novi fort and other mustahfizân of the Novi fort; ${ }^{165} 3$ ) Bekir Ağa and Ali Ağa children of Zeynihân Ağa and Feridun Ağa, son of Durak Ağa, Gâzî - leader of the harâmîs, odabaşı Veli, seroda Hasan, seroda Osmân, Ömer Ağa, son of Ali, fârisân and the martoloses of the Novi fort; ${ }^{166}$ 4) Bekir Ağa, Osman and Ali Ağa, children of Zeynihân Ağa;167 5) Sefer, son of Behlül, Feridun Ağa zaim, Nuh and Mehmed, sons of Mustafa Ağa zaim; ; ${ }^{168}$ 6)

\footnotetext{
TD 622
}

162 Data of the Novi nâhiye can be found on pages 479 A, 479B, 481A, 481B, $482 \mathrm{~A}$. In the scanned document pages $480 \mathrm{~A}$ and $480 \mathrm{~B}$ are missing.

163 The çiftlik comprised of parts of zemin in the field of the Novi fort, of Pejačić mezráa (place with a derelict fort), mezraas Doljani, Gornja and Donja Mahorina, Mahori, Straža, Dalenić with grazing land, summer pasture Rujina (Rudina?) and water mills Doljan. It yielded the income of 500 akçe.

Zeynihân Ağa is most likely the progenitor of the Zenkovići or Senkovići, an eminent Muslim family mentioned by Western sources and the folklore. TD 622, $479 \mathrm{~A}$.

164 Nickname dede suggests that this was an elder of a Dervishi Order.

165 The çiftlik comprised of parts of zemin of the field Novi and parts of mezraias Ledenice, Novosel, Podoštre, Bilišan, Dugošan, Gospić (place of derelict church), Zapotočan, Smiljan, Gaćan, Podhumci, Papraćan, Šibljan, Dubnić with grazing land, summer pasture, meadow and forest. Mezra Račić possessed by the inhabitants of the Novi fort also belonged to the çiftlik. Income from the çiftlik amounted to impressive 3.320 akçe which means that farming was well developed.

166 The çiftlik comprised parts of zemin in the field of the Novi fort and parts of mezraias Ledenice, Novosel, Podoštre, Bilišan, Dugošan, Gospić (place of derelict church), Račić, Podhumci, Papraćan, Šibljan, Dubnić with grazing land, summer pasture, meadow and forest and yielded 300 akçe.

167 The çiftlik comprised of zemin field of the Novi fort and mezra'as Gornja and Donja Trnavica, Oštarije, field near Novi fort, Konjsko, Slanište with water mills, summer pasture, grazing land and meadow. It yielded 300 akçe.

168 The çiftlik comprised zemin filed of the Novi fort, mezra'as Donja Trnava and Podhumci with summer pasture, grazing land, meadow and it yielded 940 akçe. 
Mehmed zaim and Ahmed zaim; $\left.{ }^{169} 7\right)$ Behlül Bey zaim, Oruç kethüda, voyvoda Sinân, Veli Ağa Blagajlu, Mehmed Prko (?), 'Ali Bey, son of Veli, Mehmed Ağa and Mustafa. ${ }^{170}$

As the sources reveal, there were no major changes in the landownership and land possession relations in comparison to 1574. Eminent Muslims in the nâbiye and members of the Novi fort garrison still remained çiftlik holders. There are registered tax amounts per item produced for two çiftliks which means that there indeed were farming activities in those areas, while for five çiftliks only a fixed amount was registered.

Villages of the nâhiye of Novi could now - according to their economic and administrative status and their liabilities to the state, be divided as follows: a) tithe villages - giving a tithe of their farm production to the sipâbî which means that those were farming villages. To those we could add villages which gave a fixed amount from their agricultural production which was not given per item produced in the defter, b) filuri villages - villages which realised their obligation to the government through filuri (resm-i filori) ${ }^{171}$ and taxes collected from the so called "nomads" (resm-i hâymâne), and c) villages without clear indication of their status. Filuri villages in Lika were immigrant villages which have a specific agreement with the government on the exemption from cizye for a number of years and which were supposed to be left out of the sipâbî-timâr system. As fluri villages we would like to single out the following: Brušane (filuri amount 534 akçe), Novosel (534 akçe) and Lovine (1.500 akçe). As tithe villages we selected the following: Račić (belonged to the mustahfiz of the Novi fort, tithe amount was 400 akçe), Mahori (1.460), Tatačić (2.136), Komarevo (600), Donje and Gornje Podoštre (554), Vinari (430), Donji Ribnić ? (200), Zapotočje (600). Other villages had no indication registered; examples of those are: Donja and Gornja Mahorina (revenue 300 akçe), Bag (150), Jablanica (220), Doljan (200), Dugošani (220) and Ribnik (230). For no village was a number of taxpayers recorded, and thus we cannot assess demographic situation in the nâhiye or an approximate number of inhabitants. However, amounts of taxes collected definitely tell us something about the level of development of farming and thus also of the importance (perhaps even size) of the villages. Thus we can say that Lovine stand out among the filuri villages, while Tatačić and Mahori stand out among the tithe villages. As far as other duties are concerned, bac was still being

$\overline{169}$ The çiftlik comprised the village of Lovine and mezra'a Lovinac. TD 622, 482 /A.

170 The çiftlik comprised parts of zemin field of the Ribnik fort, peninsula of St. Nicholas church with water mills, fish pond, grazing land, meadow and part of the village of Lika, as well as winter pasture in the village of Doljan with Gorić. The census taker assessed the income from this çiftlik to be 300 akçe as was put down in the previous register. TD 622, 482 /A.

${ }^{171}$ Filuri - so called "ducat tax," or "florin tax" (Lat. Florenus). Basic tax for the Vlach population, and population of similar status. Each Vlach household (as a tax unit) paid a florin. 
collected in the nâhiye which means that market day was being held where trading was done. The government also collected all of the above referenced petty fines, bride tax, tâpu-izemin and fee for agricultural damage.

In 1585 in the nâbiye of Medak the total of 19 villages were registered, as well as 7 çiftliks and 7 mezra'as as independent tax units. Some villages were entered twice, depending on the regulation of tax collection from their inhabitants. The following villages were fluri: Srijani (800 akçe), Lapac (800), Veliki and Mali Novak, Novak Selište (800), Mali Srčani (1.250), Došlak (404), Kolčić (500), Zavrna (? 1.200), Ogorane (1.000), Ogorani (405), Kupusar (450), Pod (?, 2.000), Poljana - place of St. John's church (1.600), Dubavica (600), Mala and Velika Ribnica (?, 450). In addition to the fluri there were also villages whose duties were so regulated that they were giving "product of nomads" (mahsûl-i hâymâne) and bâd-u havâ, instead of filuri. For such villages a number of baştines is entered which tells us the movements of the taxpayers. Here we could argue were those villages or parts of villages which were inhabited for a longer time period. Such villages were the following: Počitelj (3 Christian baştines), Ribnić (?) place of St. Lovrinac church (5 Christian and 1 Muslim baştines), Zavrna (4 Christian baştines) ${ }^{172}$, Namlina (?) Donja (2 Christian baştines), Hrelić (3 Christian baştines). This is a rather small number of baştines - only 17 Christian and 1 Muslim baştines. A few mezra'as were recorded in the nâhiye which were also populated by new immigrants because the government collected filuri there as well as resm-i hâymâne: mezra'as Dobro (600 akçe), Počrnice (540), Radunić (620), Dragavić (700), Vinak (560) and Bunić (620), while mezra'as Velika and Mala Ribnica (?) were possessed by notary Hüseyin.

As çiftlik holders in the Medak nâhiye the following individuals were recorded: 1) Nuh son of Murâd Ağa and Süleyman son of Hasan Ağa; ${ }^{173}$ 2) sipâhî Hüseyin serharâmi; ${ }^{174}$ 3) Kurd Ağa $;{ }^{175}$ 4) Hüseyin, son of Hacci Uveys and Yusûf son of Murâd; ${ }^{176}$ 5) Mustafâ, Mehmed, Mehmed Ağa Velî and Mehmed, son of Hüseyin;; ${ }^{177}$ 6) Ali Ağa, Ca'afer kethüda, Ahmed and Musa. ${ }^{178}$ The revenue from farming in the above çftliks was not entered per item produced, which means that farming in them was

172 Part of the village was registered under filuri as well which would mean that the new immigrants inhabited the previously vacant part of the village.

173 The çiftik was in the village of Miholić. TD 622, 485B.

174 The çiftlik was in the village of Gornji Srčani. TD 622, 485B.

175 The çiftlik comprised a part of the village of Počitelj, with a meadow, summer pasture and grazing land. TD 622, 486A

176 The çiftlik comprised part of the village of Srijani Donji with grazing land, meadow, summer pasture and water mills. TD 622, 486A.

177 The çiftlik comprised of a part of the village of Žagar with grazing land, summer pasture and meadow. TD 622, 486A.

178 The çiftlik comprised of the Komnić mezra'a with grazing land, summer pasture, meadow and water mills. TD $622,486 \mathrm{~B}$. 
at low levels. Ciftlik/mezráa Komlić with meadow and water mills was registered in the defter without assigned user, but it can be assumed that the çiftlik/mezra'a was inhabited by immigrants because the government collected only filuri and resm-i haymâne from it, and the amount was quite high -2.550 akçe. ${ }^{179}$

The nâbiye of Bilaj Barlete had five villages registered in 1585, as well as two mezraias as one tax unit and 8 çftliks. There were three functioning mills in the nâbiye kept by inhabitants of the Barlet Bilaj fort, and the state collected 45 akçe from them.

Number of inhabitants is not entered for any village, and tax burden for those villages was regulated with a filuri as was the case with the other two nâbiyes, which supports a thesis that they were recently colonised, and that they were oriented toward stock breeding and semi-military duty. The village of Vrbčić gave 5.000 akçe as fluri and resm-i hâymâne; such a high amount tells us that there were many inhabitants in the village. The village of Gorica was registered twice with the same amount of fluri (400 akçe). It is not known whether those are two separate localities or two parts of the same village. ${ }^{180}$ The village of Dupčan was according to the amount of fluri (700 akçe) a small village. Toponym which we could deduce from karye-i Liçka most likely denotes Ličko selo which was paying only 100 akçe as filuri. ${ }^{181}$ The village of Lika was registered in the nâbiye of Novi in a çiftlik on the Ribnik area and is therefore most likely the same village whose taxes collected were forwarded to different places. Mezráas Dubovac and Miovci had the martoloses as inhabitants who also paid fluri and resm-i hâymâne (304 akçe). ${ }^{182}$

As far as çiftliks are concerned, there were eight. Tax on revenue from farming on ciftliks was registered without breakdown per item of farm product, namely, only the total amount in akçe is given. The amounts vary between 300 and 1.300 akçe. ${ }^{183}$ The following persons are registered as çiftlik holders: 1) Keepers (mustahfizân) of the Barlet Bilaj fort; ${ }^{184}$ 2) İbrahim, son of Mustafâ, ağa of azaps of the Barlet Bilaj fort and Mustafa, kethüda of azaps of the Barlet Bilaj fort; ${ }^{185}$ 3) Mehmed A ğa, İbrahim Ağa and 'Ali serharâmi; ${ }^{186}$ 4) the mustahfizân of the Barlet Bilaj fort; ${ }^{187}$ 5) 'Ali Ağa of the martoloses of the Barlet Bilaj fort, Hürrem son of Abdullâh, Yusûf son of

TD $622,485 \mathrm{~A}$

180 See TD 622, 490A i 490B.

181 TD 622, 490B

182 TD 622, 490A

183 TD 622, 490 A-490B.

184 The source does not give details on the position of çiftlik, most likely it was under the Barlet Bilaj fort.

185 The çiftlik comprised part of zemin field of Barlet Bilaj. TD 622, 490A.

186 The çiftlik comprised Dupčan mezrá. TD 622, 490A.

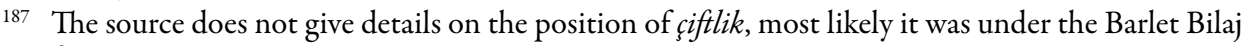
fort. 
Abdullâh, Hasan son of 'Ali and Recep Abdullah; ${ }^{188}$ 6) Janko (?) and knez Miloš, son of Ugarak; ${ }^{189} 7$ ) Mehmed, Mustafâ, Hasan and Hüseyin, sons of Murâd; ${ }^{190}$ 7) Murâd Ağa, dizdar of the Bilaj Barlete fort, Ca'afer son of Velî sermartolos, the martoloses and the mustahfizân of the fort; ${ }^{191} 8$ ) 'Ömer and Osmân, sons of Ahmed and Ferhâd, son of Abdullâh. ${ }^{192}$

In all three of the above nâhiyes in 158542 villages, 22 çftliks and 8 mezra'as as separate tax units were recorded what is an considerable increase in comparison to 1574 when 37 villages, 20 çiftliks and 2 mezra'as as separate tax units were recorded.

\section{CONCLUSION}

Ottoman rule in Lika in the course of the $16^{\text {th }}$ century was established with difficulties. This vast area was controlled from three forts - Novi, Bilaj and Udbina. The territory was extremely sparsely populated, and depopulation was great. In 1530 in the nâhiyes of Lika there were about 40 mezra'as registered. No settlement was at that point registered as a village (karye). However, it seems that Lika had more inhabitants at the beginning of the Ottoman rule around 1528-30 then in 1550. As a result of great insecurity and inability to farm the land the remaining population moved deeper into the Ottoman inland or fled to the Habsburg side, thus leaving the land in the border area vacant and unfarmed. Large parts of the vacant land were turned into tenant farm land or çiftliks assigned to interested individuals for low fixed amounts.

From mid- $16^{\text {th }}$ century Ottomans have been taking concrete measures for repopulation of Lika and reconstruction of fort infrastructure. Gračac is reconstructed, and in our researched area - the Ribnik and Barlete forts as well. Settlement of Lika, namely of Ličko polje, was an extremely slow process. Regional Ottoman authorities have invested efforts throughout twenty years to repopulate the terri-

188 The çiftlik comprised of part of zemin field of Barlet Bilaj, part of Ribnica (?), part of zemin of St. Peter's church and part of Srednja Gora. TD 622, 490B.

189 The çiftlik comprised of the villages of Gornji and Donji Barlet with water mills, summer pasture, grazing land and meadow. TD 622, 490B. We should stress here that the term Vlach (Eflâkân) in reference to the inhabitants of certain villages is here used only in the first register of 152830 , while the later registers do not employ the term anymore. However, the title of the knez in reference to certain Vlach elders is still in use.

190 The çiftlik comprised of a part of zemin field of the Bilaj Barleta fort, mezra'a Gorica, part of mezráas Slana, Srednja Gora, part of St. Peter's zemin with grazing land and summer pasture. TD 622, 490B.

191 The çiftlik comprised of parts of zemin field of the Bilaj Barleta fort, mezra'as Dupčani, Ribnica (?), part of St. Peter's church zemin, part of Srednja Gora mezra'a with grazing land, summer pasture and meadow. TD 622, 490B.

192 The çiftlik comprised part of Podvrebac mezra'a with grazing land, summer pasture, meadow and water mills. TD 622, 490B. 
tory employing the policy of istimâlet and of giving guarantees and tax exemptions. New inhabitants arrived from all directions (her canibinden); they were mostly transhumance cattle breeders from the sancâks of Klis or Herzegovina but there were also immigrants from the border area with the Habsburg Monarchy. With an increase in the number of inhabitants nâbiyes were defined and borders between them outlined. The results of the Ottoman repopulation policy were visible in the census of 1574 when for the said three nâbiyes the total of 37 villages was recorded, 18 of which were in the nâbiye of Novi, 5 in the nâbiye of Bilaj Barlete and 14 in the nâhiye of Medak. Also, in the three researched administrative units the total of 20 çiftliks was registered, 9 of which in Novi, 4 in Bilaj Barlete and 7 in Medak. The nâbiye of Novi was the most extensive and had the greatest number of villages and çiftliks, while the nâhiye of Bilaj Barlete was the smallest administrative units in area and had a modest number of villages and çiftliks. According to their tax and administrative status the villages can be divided into tithe and filuri villages. Çiftliks encompassed parts of fine land with meadows, grazing land, water mills, summer pastures, even fish ponds which are registered for two places in the nâhiye of Novi. Ciftlik holders in the nâbiyes of interest were mostly members of the fort garrison, military commanders, and their descendants whose families grew in importance to the extent that they became the main landowners in Lika. However, çiftlik holders were not members of fort garrisons exclusively; they were held by Ottoman notables from the military and administrative apparatus, such as sancâkbeyis and voyodas as well as Vlach knezes who were thus incentivised to settle the vacant areas with their communities or cemâats. Settlement of Lika continued after 1574, and the next register from 1585 for the three researched nâbiyes registered the total of 42 villages, 22 çftliks and 8 mezra'as as separate tax units, of which the nâbiye of Novi had 18 villages and 7 çftliks, Medak had 19 villages, 7 çiftliks and 7 mezra'as, while Bilaj Barlete had 5 villages, 8 çiftliks and 1 mezráa.

\section{BIBLIOGRAPHY}

\section{UNPUBLISHED ARCHIVAL SOURCES}

Başbakanlık Osmanlı Arşivi (BOA), Istanbul.

Tapu Tahrir Defteri (TD) 157, 164, 284, 285, 533, 622

Maliyeden Müdevver Defterler (MAD) 540

Mühimme Defteri Vol. 3, 5, 7, 9, 12, 14, 46, 48, 58

Tapu ve Kadastro Genel Müdürlüğü, Kuyûd-i Kadime Arşiv (TK. KKA), Ankara.

Tapu Defteri 119 


\section{PUBLISHED SOURCES}

Batinić, Mijo. "Njekoliko priloga k bosanskoj crkvenoj povijesti." Starine JAZU XVII (1885): 115-145.

Bogović, Mile. “Takozvani Glavinićev opis Like i Krbave iz 1696. godine." Croatica Christiana Periodica. 15/27 (1991): 117 - 128.

91, 164, MAD 540 ve 173 numaralı - Hersek, Bosna ve İzvornik livâlari icmâl tahrîr defterleri I-II (926-939 / 1520-1533). Ankara: T.C. Başbakanlık Devlet Arşivleri Genel Müdürlüğü Osmanlı Arşivi Daire Başkanlığı, 2006.

Lopašić, Radoslav. Spomenici Hrvatske krajine. Knjiga 1. Od godine 1409. do 1610. Zagreb: Academia scientarium et artium Slavorum meridionalium, 1884.

Pečevija, Ibrahim Alajbegović. Historija 1520-1576. Svezak 1. Translated by Fehim Nametak. Sarajevo: El Kalem, 2000.

Polić-Bobić, Mirjana. "Dva izvještaja o naseljavanju muslimana u Liku i Krbavu.” Radovi Zavoda za hrvatsku povijest 24 (1991): 207-210.

Spaho, Fehim Dž., Ahmet Aličić and Behija Zlatar. Opširni popis Kliškog sandžaka iz 1550. godine. Sarajevo: Orijentalni institut, 2007.

Rački, Franjo. "Prilozi za geografsko-statistički opis Bosanskoga pašalika." Starine JAZU XIV (1882): 173-195.

\section{LITERATURE}

Antoljak, Stjepan. "Kada i koliko puta je osnivan Krčki ili Lički sandžak?.” Zadarska revija 2 (1957): 160-166.

Hafizović, Fazileta. "Posjedi zvaničnika i njihovih porodica u Kliškom sandžaku u 16. stoljeću." Znakovi vremena 13/ 48-49 (summer-autumn 2010): 228257.

Holjevac, Željko and Moačanin, Nenad. Hrvatsko-slavonska Vojna krajina u ranome novom vijeku i Hrvati pod vlašću Osmanskoga Carstva u ranome novome vijeku. Zagreb: Leykam International, 2007.

Holjevac, Željko. “Ličko-krbavska županija u identitetu Like.” In Identitet Like: korijeni $i$ razvitak, edited by Željko Holjevac, 429- 465. Zagreb - Gospić: Institut društvenih znanosti Ivo Pilar - Područni centar Gospić, 2009.

Horvat, Rudolf, Lika i Krbava. Povijesne slike, crtice i bilješke. Zagreb: Izdanje Matice Hrvatske, 1941.

Husić, Aladin. "Vojne prilike u splitsko-zadarskom zaleđu u 16. stoljeću (osmanski serhat 1530-1573)" Prilozi za orijentalnu filologiju 56 (2006): 125-144.

Husić, Aladin. "Tvrđave Bosanskog sandžaka i njihove posade 1530. godine." Prilozi za orijentalnu filologiju 49 (1999): 189-230. 
Jakovljević, Aleksandar - Isailović, Neven. Petrovo polje u vrelima osmanskog razdoblja (1528.-1604.). Šibenik: Državni arhiv u Šibeniku - Javna ustanova Nacionalni park Krka, 2019.

Juran, Kristijan. "O podrijetlu i šibenskoj rodbini prvoga kliškog sandžakbega Murat-bega Gajdića." Prilozi za orijentalnu filologiju 66 (2016): 231-239.

Jurin Starčević, Kornelija. "Vojne snage Kliškog i Krčko-ličkog sandžaka pred Kandijski rat - osmanska vojska plaćenika." In Zbornik Mire Kolar Dimitrijević, edited by Damir Agičić, 79-95. Zagreb: FF press and Odsjek za povijest Sveučilišta u Zagrebu, 2003.

Kreševljaković, Hamdija. Kapetanije u Bosni i Hercegovini. Sarajevo: Svjetlost,1980. Kruhek, Milan. "Turske utvrde i kule u Lici i Krbavi 1527.-1689. godine." Senjski zbornik 40 (2013): 471-508.

Mataija, Ivica. "Lička Toponimija." Doctoral Thesis, University of Zadar, 2019.

Mažuran, Ive. Hrvati i Osmansko Carstvo. Zagreb: Golden marketing, 1998.

Moačanin, Nenad. "Ime Gospić u svjetlu turskih izvora." Croatica christiana periodica 26 (1990): 51-54.

Moačanin, Nenad. "Naseljenost Like i izvori feudalne rente početkom XVII. stoljeća pod turskom vlašću." Historijski zbornik XLVI (1993): 61-65.

Moačanin, Nenad. Turska Hrvatska. Hrvati pod vlašću Osmanskoga Carstvo do 1791. Preispitivanja. Zagreb: Matica hrvatska, 1999.

Pavičić, Stjepan. "Seobe i naselja u Lici." Zbornik za narodni život i običaje južnih Slavena 41 (1962): 5-330.

Spaho, Fehim Dž.. "Organizacija vojne krajine u sandžacima Klis i Krka u XVII. stoljeću." In Vojne krajine u jugoslovenskim zemljama u novom veku do Karlovačkog mira 1699.godine, edited by Vasa Čubrilović, 101-114. Beograd: SANU, 1989.

Spaho, Fehim Dž.. "Neke karakteristike razvitka varoških naselja u Kliškom sandžaku u XVI. i XVII. stoljeću.” Prilozi za orijentalnu filologiju 38 (1989): 241-251.

Šarić, Marko. "Društveni odnosi i previranja u sandžaku Lika - Krka u 16. i početkom 17. stoljeća.” In Diplomska radionica prof. dr. Drage Roksandića, edited by Drago Roksandić and Nataša Štefanec, 67-130. Zagreb: Zavod za hrvatsku povijest, 1999.

Šarić, Marko. “Osmanski korijeni Gospića: nahija Novi u 16. i 17. stoljeću." Povijesni prilozi 42 (2012): 215-248.

Šabanović, Hazim. Bosanski pašaluk. Postanak i upravna podjela. Sarajevo: Svjetlost, 1982.

Zahirović, Nedim. “Tragom jedne karijere: Halil-beg (Halil-paša) Memibegović od Like preko Jegra do Banja Luke.” Historijski zbornik LXX, no. 2 (2017): 353-364. 